\title{
Fordító- és tolmácsképzés Németországban ${ }^{1}$
}

\author{
Fáy Tamás \\ E-mail:fay.tamas@uni-eszterhazy.hu
}

\begin{abstract}
Kivonat: A németországi fordító- és tolmácsképzés egységes kezelését megnehezíti az a tény, hogy a képzések formai-tartalmi kérdései az egyes tartományok hatáskörébe tartoznak, bár a felsőoktatás Bologna-rendszerre való átállása javarészt egységes keretek közé terelte a korábban rendkívül szerteágazó és összetett képzési struktúrát. Ugyanakkor a németországi fordító- és tolmácsképzés jelen pillanatban is komoly változásokon megy keresztül, hogy megfeleljen a folyamatosan változó munkaerőpiaci igényeknek és a technológiai újításoknak, illetve választ adjon a globalizációs folyamatok nyomán kialakult helyzetre. A tanulmányomban egy rövid történeti áttekintés után a különféle képzési lehetőségeket kívánom bemutatni áttekinthető formában: Kitérek az egyetemi szakkínálatra, az ipari és kereskedelmi kamarák által szervezett vizsgákra, az állami vizsgák (még mindig kevésbé egységes) rendszerére, és a nyelvi közvetítők sajátos helyzetére. A dolgozat a fontosabb tanulságok összegzésével zárul.

Kulcsszavak: fordítóképzés, tolmácsképzés, nyelvi közvetítők, hiteles fordítás, fordítóipar, felesketés, állami fordítóvizsgák, állami tolmácsvizsgák, kamarai fordítói és tolmácsvizsgák
\end{abstract}

\section{Bevezetés}

„Geprüfter Übersetzer“ („vizsgáztatott fordító”), „öffentlich bestellter Übersetzer“ („,nyilvánosan kirendelt fordító”), „vereidigter Dolmetscher“ (,felesketett tolmács”), „Diplom-Übersetzer“ („,diplomás fordító”) stb. - Németországban, részben a föderatív államszerkezet miatt, számos kifejezést használnak a nyelvi közvetítők megnevezésére, amelyek között nem mindig könnyü különbséget tenni. A jelen tanulmány áttekinthető, de kellően részletes formában kívánja bemutatni a németországi fordító- és tolmácsképzést, kitérve az egyes képesítések és végzettségek közötti különbségekre. Ezenkívül a fordítók és tolmácsok felesketésének rendsze- 
rét is bemutatja, mivel sok képzési forma a felesketés vagy a felhatalmazás elöfeltételének számít, vagy kifejezetten arra készít fel. A témával kapcsolatban ugyan több (inkább vázlatszerü) írás is napvilágot látott, amelyekre a jelen tanulmány is hivatkozik, azonban eddig még (különösen magyar nyelven) nem jelent meg egy valóban szisztematikus áttekintés. A tanulmány ezt a hiányt kívánja pótolni, a hangzó nyelvek közötti írásbeli és szóbeli közvetítésre helyezve a hangsúlyt, ezért a jelnyelvi tolmácsolás különféle formái, illetve az ezen a néven meghirdetett szakok (,,deaf studies” stb.) értelemszerüen nem képezik a vizsgálat tárgyát. A tanulmány arra a kérdésre keresi a választ, hogy a pálya iránt érdeklődők milyen képzési formák és vizsgatípusok közül választhatnak. Reményeim szerint a dolgozat a magyarországi fordító- és tolmácsképzést kutató szakembereknek, illetve a képzésben részt vevő oktatóknak és hallgatóknak is értékes támpontokat adhat.

\section{Történeti áttekintés: A német fordító- és tolmácsképző intézmények}

A német fordító- és tolmácsképzés hosszú múltra tekint vissza. Ebben a fejezetben a fejlödés legfontosabb állomásait szeretném bemutatni. Részletesebb történeti áttekintésre azért nem vállalkoztam, mert az túlmutatott volna a tanulmány keretein, viszont a nagyobb mérföldkövek felvázolása hozzájárul a téma alaposabb megértéséhez.

A tolmácsolás, amelyet sokan a „második legősibb mesterségnek” neveznek, filogenetikai és ontogenetikai szempontból is elsődleges a nyelvi közvetítés írott formájával szemben, így nem meglepö, hogy (a fordítással szemben) elsődlegességet élvezett az (egyetemi) oktatásban, és az intézményesített bevezetésére is korábban került sor.

Az egyetemi szintű nyelvi közvetítés első állomását a Keleti Nyelvek Szemináriumának (SOS/Seminar für Orientalische Sprachen) megalapítása jelenti, amely Bismarck kezdeményezésére 1887-ben jött létre a berlini Friedrich-WilhelmsEgyetemen (mai nevén Humboldt Egyetemen). A Szeminárium elsődleges célja az volt, hogy a leendő tolmácsok számára lehetővé tegye a keleti nyelvek gyakorlati alkalmazását (lásd Skalweit 2017: 79).

Az első, kifejezetten tolmácsképzés céljából alapított iskola az 1929-ben² (más források szerint 1930-ban ${ }^{3}$ ) a mannheimi kereskedelmi föiskolán létrehozott Fordító- és Tolmácsintézet (IÜD / Institut für Übersetzen und Dolmetschen) volt, amely a föiskola 1993-as megszünése óta a Heidelbergi Egyetemen müködik, és Európa-szerte az egyik legrégebbi fordító- és tolmácsképző intézetnek számít.

Hogy ekkoriban hány képzett tolmács dolgozott a „piacon”, arról nincsenek pontos információk, de az biztos, hogy a nürnbergi per során bevont 300 nyelvi közvetítö közül csak néhányan voltak képzett tolmácsok. ${ }^{4}$ Az 1945 -ös évet egyébként a szinkrontolmácsolás születésnapjának szokás tekinteni, részben azért, mert a nürnbergi per tolmácsok hiányában nem vagy teljesen máshogy zajlott volna le. A nyelvi közvetítők jelentőségét jól mutatja a következö, Göringtől (a per egyik fő 
vádlottjától) származó idézet: „Nem ügyvédre van szükségem [...] Amire valóban szükségem van, az egy jó tolmács." (idézi Kalverkämper/Schippel 2008: 37) Az is bizonyos, hogy a nürnbergi per elött a szinkrontolmácsolás nem volt annyira elterjedt ${ }^{5}$ (a fülbesúgás vagy susotázs mint a szinkrontolmácsolás egyik válfaja nyilván hosszabb múltra tekint vissza). Szinkrontolmács-berendezéseket ugyan már 1927ben is használtak, de ezek az IBM által kifejlesztett és a feltalálóik neve alapján Filene-Finlay-rendszernek nevezett berendezések még úgy müködtek, hogy a szövegeket előzetesen le kellett fordíttatni, később pedig a beszédek elhangzásakor a tolmácsok szinkron módon felolvasták a lefordított szövegeket (vö. AIIC 2013). A nürnbergi per több szempontból is úttörő vállalkozásnak számított a tolmácsolás történetében: 1) a tolmácsok nagy száma, 2) a tolmácsolt nyelvek nagy száma (német, angol, francia, orosz), és 3) a munkakörülmények miatt, hiszen a tolmácsok - csakúgy, mint ma - kabinokban ültek, és egy (kifejezetten a per céljából továbbfejlesztett) szinkronberendezést használtak.

Ma már nehéz megmondani, hogy a nürnbergi per milyen hatást gyakorolt a tolmácsképzésre, viszont a második világháború után több, még ma is működő intézet jött létre, és Németországban szintén ekkor alakultak az első szakmai szervezetek, vö. Schlesiger 2017: 34 (pl. 1948-ban megalapították a németországi Fordítók és Tolmácsok Szövetsége, azaz a BDÜ bajorországi tagszervezetének elődjét $\left.{ }^{6}\right)$.

A germersheimi „Állami Tolmácsföiskola” 1947-ben kezdte meg, majd 1949től „Nemzetközi és Tolmácsintézet” (Auslands- und Dolmetscherinstitut) néven a mainzi Johannes Gutenberg-Egyetemen folytatta müködését ${ }^{7}$, végül 2009-ben „Transzláció-, Nyelv- és Kultúratudományi Egység” (FTSK / Fachbereich Translations-, Sprach- und Kulturwissenschaft) névre keresztelték. Ma a világ egyik legnagyobb és legismertebb fordító- és tolmácsképző intézete, amely 2019-ben ünnepelte fennállásának 70. évfordulóját, az egyetem germersheimi kampuszán található.

Az erlangeni „Idegen Nyelvi és Nemzetközi Tanulmányok Intézete” (IFA / Institut für Fremdsprachen und Auslandskunde) 1948-ban jött létre, amivel szintén az egyik legrégebbi idegen nyelvi iskolának számít Németországban. ${ }^{8}$

A Saarbrückenben található Saar-vidéki Egyetem Tolmácsintézete is 1948-ban nyílt meg, és kezdetben kartól független formában, majd később a Bölcsészettudományi Kar részeként müködött. ${ }^{9}$ Az első években franciát és angolt tanítottak, majd a nyelvi kínálat az olasszal, az orosszal és a spanyollal bővült. Ma a fordító- és tolmácsképzés a Saar-vidéki Egyetem Nyelvtudományi és Nyelvtechnológiai Szakirányán (Fachrichtung Sprachwissenschaft und Sprachtechnologie) folyik.

A Müncheni Nyelvi és Tolmácsintézet (SDI / Sprachen \& Dolmetscher Institut München) 1951-ben nyitotta meg a kapuit ${ }^{10}$ (az alapítást gyakran tévesen az intézet legismertebb igazgatójának, Paul-Otto Schmidtnek, Adolf Hitler hivatalos tolmácsának tulajdonítják $\left.{ }^{11}\right)$. Az első évben angol, francia és olasz nyelven folyt a képzés, később ez kiegészült az olasszal, orosszal és kínaival. Érdekességképpen: A rekordévnek számító 1976-os évben több mint 1800 diák járt az intézetbe. 
Lipcsében már 1937 és 1945 között is folyt fordító- és tolmácsképzés, majd 1956-ban az akkori Karl-Marx-Egyetemen (mai nevén Lipcsei Egyetemen) megalapították a Tolmácsintézetet (Dolmetscherinstitut). ${ }^{12} \mathrm{~A}$ város fordítástudományi szempontból nemzetközi szinten is hallatott magáról: 1965-ben Lipcse adott otthont a világviszonylatban is első nemzetközi fordítástudományi konferenciának (Salevsky 2009: 111), és az Otto Kade, Gert Jäger és Albrecht Neubert vezetésével létrejött ún. Lipcsei Iskola komoly elméleti munkával járult hozzá a fordítástudomány fejlődéséhez és a transzlatológia (fordítás és tolmácsolás) nemzetközi elfogadottságához. Több átszervezés és átnevezés után az intézet ma a Lipcsei Egyetem Bölcsészettudományi Karán müködik „Alkalmazott Nyelvészet és Transzlatológia" (IALT / Institut für Angewandte Linguistik und Translatologie) néven.

Az ezt követő években folyamatosan bővült a képzési kínálat, az előzőekben felsorolt intézményeken kívül a képzés ma jellemzően a különféle egyetemek vonatkozó alap- és mesterszakjain zajlik.

\section{Képzések}

Németországban ma a fordítók és tolmácsok számos képzés közül választhatnak, ami részben a hagyományokban gazdag múltnak, és föleg annak köszönhető, hogy az oktatáspolitika az egyes tartományok hatáskörébe tartozik. Ettől függetlenül fontos hangsúlyozni, hogy a „fordító” és „tolmács” elnevezést Németországban semmilyen törvény nem védi, tehát ma bárki folytathat fordítási és tolmácsolási tevékenységet, ehhez nem kell elvégeznie egy képzést vagy letennie egy vizsgát (az USA-ban is hasonló a helyzet, vö. Vermes 2017: 82). A Bologna-folyamat némi egységességet teremtett ezen a téren, aminek következtében „diplomás fordító (,Diplom-Übersetzer”), „,diplomás szakfordító” („Diplom-Fachübersetzer”), ,diplomás tolmács” („Diplom-Dolmetscher”), „egyetemen vizsgázott fordító” (,akademisch geprüfter Übersetzer”) stb. végzettséget már nem lehet szerezni.

\subsection{Egyetemi képzések}

Sok más országhoz hasonlóan a fordítók és tolmácsok képzése Németországban is elsősorban alap- és mesterszinten zajlik, a tudományos pályára törekvő hallgatók pedig az egyetem elvégzése után beiratkozhatnak valamelyik fordítástudományi doktori programra. A következő fejezetekben ezeket a képzéseket mutatom be részletesebben, és a sajátos bajorországi helyzetre is kitérek.

\subsubsection{Alapképzés}

Az alapképzésben (BA) többnyire három nyelv kombinációjából lehet választani: Az „A" nyelv az anyanyelv (ez többnyire a német), a két idegen nyelv pedig a „B” és a „C" nyelv. A „B” az aktív idegen nyelv (amiből és amire fordítanak), a „C” nyelv 
pedig a passzív idegen nyelv (amiből fordítanak), sok idegen nyelvet azonban a kereslettől függően hirdetnek meg. Több helyen arra is van lehetőség, hogy ne a német legyen az „A” nyelv, ez azonban mindig az adott intézmény kapacitásától függ.

A többnyire hat szemesztert felölelő alapképzés számos különböző néven fut („fordítástudomány”, „transzlatológia”, „transzlációtudomány”) (lásd Nord 2013: 179 is), és a Bachelor of Arts (BA) diplomával zárul. Az egyes szakok részleteit illetően elég változatos a kép, de a formai követelményeken (érettségi, nyelvtudás igazolása stb.) kívül többnyire nem írnak elő egyéb kötelezettséget, tehát ha ezeket teljesítik a jelentkezők, akkor automatikusan bejutnak a kiválasztott egyetemre. A legtöbb képzést nappali tagozaton (,Vollzeitstudium”) hirdetik meg. Néhány intézmény - egyesítve az elméletet és a gyakorlatot - duális képzést kínál, ami egy gyakorlatorientált szakma esetében, mint amilyen a fordítás és a tolmácsolás, elég kézenfekvő megoldás.

Az 1. sz. táblázat az egyes alapszakokról nyújt áttekintést (tartományokra lebontva), amelyek jelenleg (2020 januárjában) kifejezetten a fordítók és tolmácsok képzésére irányulnak. A táblázatban így nem szerepelnek azok a szakok, amelyek ugyan fordítási és tolmácsolási kompetenciákat is közvetítenek, azonban inkább a kommunikatív készségekre helyezik a hangsúlyt (pl. gazdasági kommunikáció, turizmusmenedzsment, kultúratudomány, international business communication, gazdaság és nyelvek, nemzetközi szakkommunikáció stb.).

\section{1. táblázat}

\section{Fordítási/tolmácsolási BA-szakok tartományonként}

\begin{tabular}{|c|c|c|c|c|}
\hline $\begin{array}{l}\text { Tarto- } \\
\text { mány }\end{array}$ & Szak & Képző intézmény & Nyelvek & Képzés helye \\
\hline \multirow{3}{*}{ 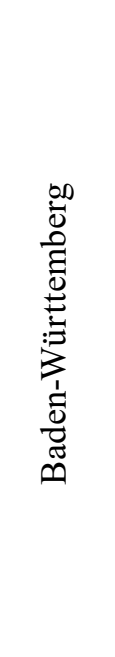 } & $\begin{array}{l}\text { BA Gazdasági/ } \\
\text { müszaki } \\
\text { szakfordítás }\end{array}$ & $\begin{array}{l}\text { AKAD (Akademiker- } \\
\text { gemeinschaft für } \\
\text { Erwachsenenbildung) }\end{array}$ & $\begin{array}{l}\text { angol, francia, } \\
\text { német, } \\
\text { spanyol }\end{array}$ & (Távoktatás) \\
\hline & $\begin{array}{l}\text { BA Fordítás- } \\
\text { tudomány }\end{array}$ & $\begin{array}{l}\text { Institut für Übersetzen } \\
\text { und Dolmetschen (IÜD), } \\
\text { Ruprecht-Karls-Universität }\end{array}$ & $\begin{array}{l}\text { angol, francia, } \\
\text { német, olasz, } \\
\text { orosz, } \\
\text { portugál, } \\
\text { spanyol }\end{array}$ & Heidelberg \\
\hline & $\begin{array}{l}\text { BA Translation } \\
\text { Studies for } \\
\text { Information } \\
\text { Technologies }\end{array}$ & $\begin{array}{l}\text { Institut für Übersetzen } \\
\text { und Dolmetschen (IÜD), } \\
\text { Ruprecht-Karls-Universität } \\
\text { Heidelberg in Kooperation } \\
\text { mit der Hochschule } \\
\text { Mannheim }\end{array}$ & $\begin{array}{l}\text { angol, } \\
\text { német }\end{array}$ & $\begin{array}{l}\text { Heidelberg, } \\
\text { Mannheim }\end{array}$ \\
\hline
\end{tabular}




\begin{tabular}{|c|c|c|c|c|}
\hline $\begin{array}{l}\text { Tarto- } \\
\text { mány }\end{array}$ & Szak & Képző intézmény & Nyelvek & Képzés helye \\
\hline 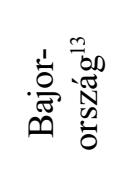 & $\begin{array}{l}\text { BA Kínai } \\
\text { fordítás }\end{array}$ & $\begin{array}{l}\text { Internationale Hochschule } \\
\text { SDI München (Hochschule } \\
\text { des Sprachen \& Dolmet- } \\
\text { scher Instituts München) }\end{array}$ & $\begin{array}{l}\text { angol, kínai, } \\
\text { német }\end{array}$ & München \\
\hline 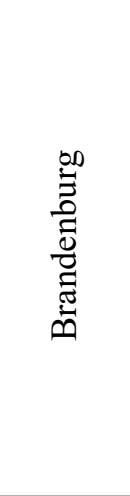 & $\begin{array}{l}\text { BA Alkalmazott } \\
\text { kultúra- } \\
\text { és transzláció } \\
\text { tudomány } \\
\text { (német-lengyel) }\end{array}$ & $\begin{array}{l}\text { Institut für Slavistik, } \\
\text { Universität Potsdam, } \\
\text { Zentrum für Sprachen } \\
\text { und Schlüsselkompeten- } \\
\text { zen, Zessko, Institut für } \\
\text { Germanistik, Universität } \\
\text { Potsdam, Institut für } \\
\text { Germanistik und Ange- } \\
\text { wandte Linguistik, } \\
\text { Maria-Curie-Skłodowska- } \\
\text { Universität in Lublin }\end{array}$ & lengyel, német & Potsdam \\
\hline 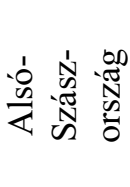 & $\begin{array}{l}\text { BA Nemzetközi } \\
\text { kommunikáció } \\
\text { és fordítás }\end{array}$ & $\begin{array}{l}\text { Institut für Übersetzungs- } \\
\text { wissenschaft und } \\
\text { Fachkommunikation, } \\
\text { Universität Hildesheim }\end{array}$ & \begin{tabular}{|l|} 
angol, francia, \\
német, \\
spanyol
\end{tabular} & Hildesheim \\
\hline 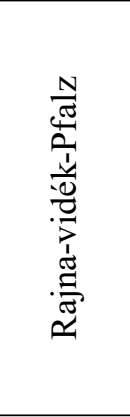 & $\begin{array}{l}\text { BA Nyelv, } \\
\text { kultúra, } \\
\text { transzláció }\end{array}$ & $\begin{array}{l}\text { Fachbereich Translations-, } \\
\text { Sprach- und Kulturwissen- } \\
\text { schaft, Johannes Guten- } \\
\text { berg-Universität Mainz, } \\
\text { Campus Germersheim }\end{array}$ & \begin{tabular}{|l|} 
angol, arab, \\
francia, \\
holland, \\
kínai, lengyel, \\
német, olasz, \\
orosz, \\
portugál, \\
spanyol, \\
török, újgörög \\
\end{tabular} & Germersheim \\
\hline \multirow{2}{*}{ 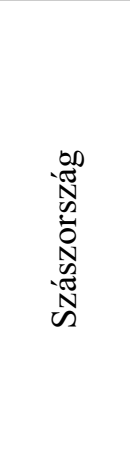 } & BA Transzláció & $\begin{array}{l}\text { Institut für Angewandte } \\
\text { Linguistik und } \\
\text { Translatologie, } \\
\text { Universität Leipzig }\end{array}$ & $\begin{array}{l}\text { angol, francia, } \\
\text { német, orosz, } \\
\text { spanyol }\end{array}$ & Lipcse \\
\hline & $\begin{array}{l}\text { BA Cseh-német } \\
\text { interkulturális } \\
\text { kommunikáció } \\
\text { és transzláció }\end{array}$ & $\begin{array}{l}\text { Institut für Slavistik, Insti- } \\
\text { tut für Angewandte Lin- } \\
\text { guistik und Translatologie, } \\
\text { Universität Leipzig und } \\
\text { Institut für Translatologie, } \\
\text { Karlsuniversität Prag }\end{array}$ & cseh, német & Lipcse, Prága \\
\hline
\end{tabular}




\begin{tabular}{|c|c|c|c|c|}
\hline $\begin{array}{l}\text { Tarto- } \\
\text { mány }\end{array}$ & Szak & Képző intézmény & Nyelvek & Képzés helye \\
\hline \multirow{2}{*}{ 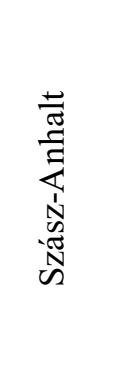 } & $\begin{array}{l}\text { BA Szakfordítás } \\
\text { - szoftver és } \\
\text { média (duális } \\
\text { képzés } \\
\text { formájában is) }\end{array}$ & $\begin{array}{l}\text { Fachbereich Informatik } \\
\text { und Sprachen (Fachbereich } \\
\text { 5), Hochschule Anhalt }\end{array}$ & német & Köthen \\
\hline & $\begin{array}{l}\text { BA Nemzetközi } \\
\text { szakkommuni- } \\
\text { káció és fordítás }\end{array}$ & $\begin{array}{l}\text { Hochschule Magdeburg- } \\
\text { Stendal (FH) }\end{array}$ & angol, német & Magdeburg \\
\hline
\end{tabular}

\subsubsection{Mesterképzés}

A mesterképzés az alapképzésre épülö, általában négyszemeszteres képzési ciklus, amely a Master of Arts (M.A) végzettséggel zárul. Az alapképzési szakokhoz hasonlóan a fordítással és tolmácsolással kapcsolatos mesterszakokat is különféle néven hirdetik meg (lásd a 2. sz. táblázatot). A mesterképzés szintén két (aktív és passzív) idegen nyelven, valamint az anyanyelven zajlik (az utóbbi általában a német vagy egy másik anyanyelv, amit a német $\mathrm{B}$-nyelvvel vagy $\mathrm{C}$-nyelvvel kombinációban hirdetnek meg). A mesterképzési szakok általában az őszi szemeszterben indulnak, és a legtöbb esetben a formai feltételeken (érettségi, nyelvtudás igazolása, alkalmassági vizsga) kívül más követelményt nem kell teljesíteni. A tolmácsolási mesterszakhoz néhány egyetem ( $\mathrm{pl}$. Lipcse) foniátriai szakvéleményt is előír, amely a beszédhang teljesítőképességéről ad visszajelzést.

2. táblázat

Forditási/tolmácsolási MA-szakok tartományonként

\begin{tabular}{|c|c|c|c|c|}
\hline $\begin{array}{l}\text { Tarto- } \\
\text { mány }\end{array}$ & Szak & Képző intézmény & Nyelvek & Képzés helye \\
\hline \multirow{2}{*}{ 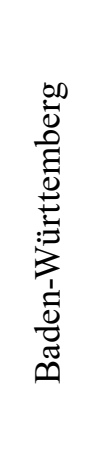 } & $\begin{array}{l}\text { MA Konferen- } \\
\text { ciatolmácsolás }\end{array}$ & $\begin{array}{l}\text { Institut für Übersetzen } \\
\text { und Dolmetschen (IÜD), } \\
\text { Ruprecht-Karls-Universität } \\
\text { Heidelberg }\end{array}$ & $\begin{array}{l}\text { angol, francia, } \\
\text { japán, német, } \\
\text { olasz, orosz, } \\
\text { portugál, } \\
\text { spanyol }\end{array}$ & Heidelberg \\
\hline & $\begin{array}{l}\text { MA Fordítás- } \\
\text { tudomány }\end{array}$ & $\begin{array}{l}\text { Institut für Übersetzen } \\
\text { und Dolmetschen (IÜD), } \\
\text { Ruprecht-Karls-Universität } \\
\text { Heidelberg }\end{array}$ & $\begin{array}{l}\text { angol, francia, } \\
\text { német, olasz, } \\
\text { orosz, } \\
\text { portugál, } \\
\text { spanyol }\end{array}$ & Heidelberg \\
\hline
\end{tabular}




\begin{tabular}{|c|c|c|c|c|}
\hline $\begin{array}{l}\text { Tarto- } \\
\text { mány }\end{array}$ & Szak & Képzó intézmény & Nyelvek & Képzés helye \\
\hline 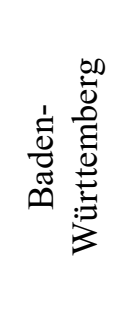 & $\begin{array}{l}\text { MA Szakfordí- } \\
\text { tás és kultúra- } \\
\text { közvetítés } \\
\text { (A fordítástudo- } \\
\text { mányi mester- } \\
\text { képzés nemzet- } \\
\text { közi változata) }\end{array}$ & $\begin{array}{l}\text { Institut für Übersetzen } \\
\text { und Dolmetschen (IÜD), } \\
\text { Ruprecht-Karls-Universität } \\
\text { Heidelberg }\end{array}$ & $\begin{array}{l}\text { angol, német, } \\
\text { spanyol }\end{array}$ & $\begin{array}{l}\text { Heidelberg, } \\
\text { Salamanca }\end{array}$ \\
\hline \multirow{4}{*}{ 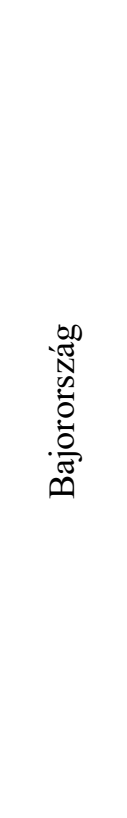 } & $\begin{array}{l}\text { MA Szak- és } \\
\text { médiafordítás }\end{array}$ & $\begin{array}{l}\text { Fakultät für angewandte } \\
\text { Natur- und Geisteswissen- } \\
\text { schaften, Hochschule für } \\
\text { angewandte Wissenschaf- } \\
\text { ten Würzburg-Schweinfurt }\end{array}$ & $\begin{array}{l}\text { angol, francia, } \\
\text { német, } \\
\text { spanyol }\end{array}$ & Würzburg \\
\hline & $\begin{array}{l}\text { MA Konferen- } \\
\text { ciatolmácsolás } \\
\text { - német-kínai } \\
\text { kettős diploma }\end{array}$ & $\begin{array}{l}\text { Internationale Hochschule } \\
\text { SDI München (Hochschule } \\
\text { des Sprachen \& Dolmet- } \\
\text { scher Instituts München) }\end{array}$ & $\begin{array}{l}\text { angol, kínai, } \\
\text { német }\end{array}$ & $\begin{array}{l}\text { München, } \\
\text { Peking }\end{array}$ \\
\hline & MA Mủfordítás & $\begin{array}{l}\text { Institut für Englische Phi- } \\
\text { lologie, Ludwig-Maximili- } \\
\text { ans-Universität München }\end{array}$ & $\begin{array}{l}\text { angol, francia, } \\
\text { német, olasz, } \\
\text { orosz, spanyol }\end{array}$ & München \\
\hline & $\begin{array}{l}\text { MA Translation } \\
\text { Management } \\
\text { - duális képzés }\end{array}$ & $\begin{array}{l}\text { Internationale Hochschule } \\
\text { SDI München (Hochschule } \\
\text { des Sprachen \& Dolmet- } \\
\text { scher Instituts München) }\end{array}$ & angol, német & München \\
\hline 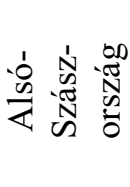 & $\begin{array}{l}\text { MA Média- } \\
\text { szöveg és } \\
\text { médiafordítás }\end{array}$ & $\begin{array}{l}\text { Institut für Übersetzungs- } \\
\text { wissenschaft und Fach- } \\
\text { kommunikation, Universi- } \\
\text { tät Hildesheim }\end{array}$ & $\begin{array}{l}\text { angol, francia, } \\
\text { német, } \\
\text { spanyol }\end{array}$ & Hildesheim \\
\hline \multirow{2}{*}{ 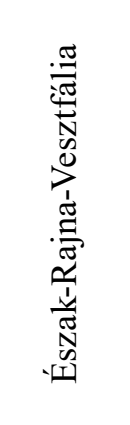 } & $\begin{array}{l}\text { MA Szak- } \\
\text { fordítás }\end{array}$ & $\begin{array}{l}\text { Fakultät für Informations- } \\
\text { und Kommunikationswis- } \\
\text { senschaften, Technische } \\
\text { Hochschule Köln }\end{array}$ & $\begin{array}{l}\text { angol, francia, } \\
\text { holland, } \\
\text { német, } \\
\text { spanyol }\end{array}$ & Köln \\
\hline & $\begin{array}{l}\text { MA Olasz: } \\
\text { Nyelv, média, } \\
\text { transzláció }\end{array}$ & $\begin{array}{l}\text { Institut für Romanistik, } \\
\text { Heinrich-Heine-Universität } \\
\text { Düsseldorf }\end{array}$ & német, olasz & $\begin{array}{l}\text { Düsseldorf } \\
\text { integrált kül- } \\
\text { földi szemesz- } \\
\text { terrel a Torinói } \\
\text { Egyetemen }\end{array}$ \\
\hline
\end{tabular}




\begin{tabular}{|c|c|c|c|c|}
\hline $\begin{array}{l}\text { Tarto- } \\
\text { mány }\end{array}$ & Szak & Képző intézmény & Nyelvek & Képzés helye \\
\hline \multirow{3}{*}{ 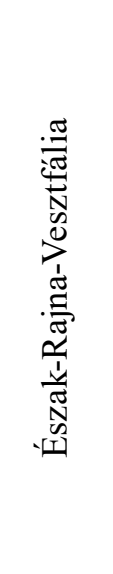 } & $\begin{array}{l}\text { MA Konferen- } \\
\text { ciatolmácsolás }\end{array}$ & $\begin{array}{l}\text { Fakultät für Informations- } \\
\text { und Kommunikationswis- } \\
\text { senschaften, Technische } \\
\text { Hochschule Köln }\end{array}$ & $\begin{array}{l}\text { angol, francia, } \\
\text { német, spa- } \\
\text { nyol }\end{array}$ & Köln \\
\hline & MA Műfordítás & $\begin{array}{l}\text { Institut für Anglistik } \\
\text { und Amerikanistik, } \\
\text { Heinrich-Heine-Universität } \\
\text { Düsseldorf }\end{array}$ & $\begin{array}{l}\text { angol, francia, } \\
\text { német, olasz, } \\
\text { spanyol }\end{array}$ & Düsseldorf \\
\hline & $\begin{array}{l}\text { MA Terminoló- } \\
\text { gia és nyelv- } \\
\text { technológia }\end{array}$ & $\begin{array}{l}\text { Institut für Translation } \\
\text { und mehrsprachige } \\
\text { Kommunikation, Techni- } \\
\text { sche Hochschule Köln }\end{array}$ & angol, német & Köln \\
\hline \multirow{3}{*}{ 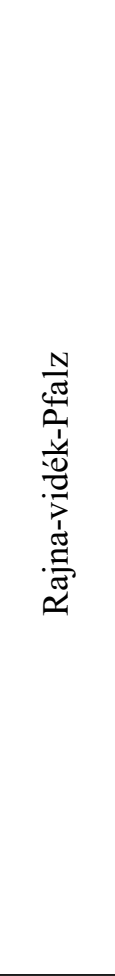 } & \begin{tabular}{|l|} 
MA Kettős \\
Mester FTSK \\
Germersheim és \\
ITIRI Stras- \\
bourg (a Masters \\
Translation hall- \\
gatói számára) \\
\end{tabular} & \begin{tabular}{|l|} 
Fachbereich Translations-, \\
Sprach- und Kulturwissen- \\
schaft, Johannes \\
Gutenberg-Universität \\
Mainz, Campus \\
Germersheim
\end{tabular} & francia, német & $\begin{array}{l}\text { Germersheim, } \\
\text { Straßburg }\end{array}$ \\
\hline & $\begin{array}{l}\text { MA Konferen- } \\
\text { ciatolmácsolás }\end{array}$ & \begin{tabular}{|l|} 
Fachbereich Translations-, \\
Sprach- und Kulturwissen- \\
schaft, Johannes \\
Gutenberg-Universität \\
Mainz, Campus \\
Germersheim
\end{tabular} & $\begin{array}{l}\text { angol, francia, } \\
\text { holland, } \\
\text { lengyel, } \\
\text { német, olasz, } \\
\text { orosz, spanyol, } \\
\text { újgörög }\end{array}$ & Germersheim \\
\hline & MA Transzláció & $\begin{array}{l}\text { Fachbereich Translations-, } \\
\text { Sprach- und Kulturwissen- } \\
\text { schaft, Johannes } \\
\text { Gutenberg-Universität } \\
\text { Mainz, Campus } \\
\text { Germersheim }\end{array}$ & $\begin{array}{l}\text { angol, arab, } \\
\text { francia, } \\
\text { holland, kínai, } \\
\text { lengyel, német, } \\
\text { olasz, orosz, } \\
\text { portugál, } \\
\text { spanyol, } \\
\text { török, újgörög }\end{array}$ & Germersheim \\
\hline 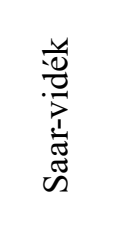 & $\begin{array}{l}\text { MA Translation } \\
\text { Science and } \\
\text { Technology }\end{array}$ & $\begin{array}{l}\text { Fachrichtung Angewandte } \\
\text { Sprachwissenschaft sowie } \\
\text { Übersetzen und } \\
\text { Dolmetschen, Universität } \\
\text { des Saarlandes }\end{array}$ & $\begin{array}{l}\text { angol, francia, } \\
\text { német, olasz, } \\
\text { spanyol }\end{array}$ & Saarbrücken \\
\hline
\end{tabular}




\begin{tabular}{|c|c|c|c|c|}
\hline $\begin{array}{l}\text { Tarto- } \\
\text { mány }\end{array}$ & Szak & Képző intézmény & Nyelvek & Képzés helye \\
\hline \multirow{6}{*}{ 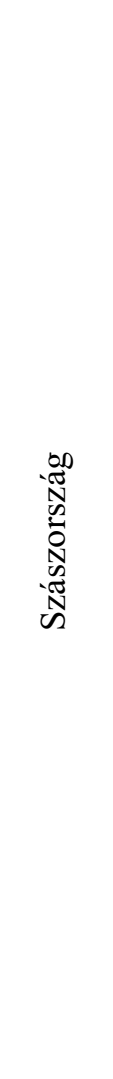 } & $\begin{array}{l}\text { MA Kettős } \\
\text { mesterszak } \\
\text { Lipcse/Stras } \\
\text { bourg (a transz- } \\
\text { latológia szak- } \\
\text { irány hallgatói } \\
\text { számára) }\end{array}$ & $\begin{array}{l}\text { Institut für Angewandte } \\
\text { Linguistik und Translato- } \\
\text { logie, Universität Leipzig, } \\
\text { Institut de Traducteurs, } \\
\text { d'Interprètes et de Relati- } \\
\text { ons Internationales, } \\
\text { Université Strasbourg }\end{array}$ & francia, német & $\begin{array}{l}\text { Lipcse, } \\
\text { Strasbourg }\end{array}$ \\
\hline & $\begin{array}{l}\text { MA Szakfordí- } \\
\text { tás arab-német }\end{array}$ & $\begin{array}{l}\text { Institut für Angewandte } \\
\text { Linguistik und Translatolo- } \\
\text { gie, Universität Leipzig }\end{array}$ & arab, német & Lipcse, Kairó \\
\hline & $\begin{array}{l}\text { MA Gazdasági } \\
\text { szakfordítás } \\
\text { német / lengyel }\end{array}$ & $\begin{array}{l}\text { Fakultät Management und } \\
\text { Kulturwissenschaften, } \\
\text { Hochschule Zittau/Görlitz }\end{array}$ & lengyel, német & Görlitz \\
\hline & $\begin{array}{l}\text { MA Konferen- } \\
\text { ciatolmácsolás }\end{array}$ & $\begin{array}{l}\text { Institut für Angewandte } \\
\text { Linguistik und Translatolo- } \\
\text { gie, Universität Leipzig }\end{array}$ & $\begin{array}{l}\text { angol, francia, } \\
\text { német, orosz, } \\
\text { spanyol }\end{array}$ & Lipcse \\
\hline & $\begin{array}{l}\text { MA Arab } \\
\text { konferencia- } \\
\text { tolmácsolás }\end{array}$ & $\begin{array}{l}\text { Orientalisches Institut, } \\
\text { Universität Leipzig }\end{array}$ & arab, német & Lipcse \\
\hline & $\begin{array}{l}\text { MA Transzlato- } \\
\text { lógia }\end{array}$ & $\begin{array}{l}\text { Institut für Angewandte } \\
\text { Linguistik und Translatolo- } \\
\text { gie, Universität Leipzig }\end{array}$ & $\begin{array}{l}\text { angol, francia, } \\
\text { német, orosz, } \\
\text { spanyol }\end{array}$ & Lipcse \\
\hline
\end{tabular}

\subsubsection{Szakakadémiák}

Bajorországban, a többi tartománnyal ellentétben, a fordítóképzés az úgynevezett szakakadémiákon (Fachakademie) zajlik, amelyek nem tudományos, hanem szakképzési intézmények, így a hallgatók a képzés sikeres elvégzése esetén nem kapnak tudományos fokozatot (diplomát). Ez természetesen nehezíti a piaci érvényesülésüket, és leszükíti az általuk elérhető továbbképzési lehetőségeket. A kedvezötlen helyzet ellensúlyozására a nyolc ${ }^{14}$ bajorországi szakakadémia közül több is - valamelyik bajorországi egyetemmel együttmüködve - BA-kurzusokat kínál, amelyek az ,államilag elismert fordító” vagy ,államilag elismert fordító és tolmács” (lásd a 3.2. fejezetet) képzéssel párhuzamosan zajlanak, így a hallgatók a tanulmányaik végén felsőfokú végzettséget tudnak szerezni.

A fordítók és tolmácsok BA-képzését tehát Bajorországban általában nem önálló képzésként hirdetik meg (a kivételeket lásd az 1. táblázat „Bajorország” részében), így ott az érettségi megszerzése után nem lehet közvetlenül jelentkezni egy 
egyetem fordító vagy tolmács BA-képzésére, hanem előbb be kell iratkozni egy szakakadémia ,államilag elismert fordító”, ,államilag elismert fordító és tolmács” stb. képzésére, és csak utána lehet elkezdeni az alapképzést. Ez a párhuzamos képzés csak az első tudományos fokozat (bachelor) megszerzésére érvényes, a mesterképzés a többi tartományhoz hasonló módon zajlik (2. táblázat).

A Müncheni Nyelvi és Tolmácsintézetben a BA-fokozat külső vizsga (Externenprüfung) útján is megszerezhető. Ezzel a lehetőséggel azok élhetnek, akik „megfelelő végzettséggel rendelkeznek ahhoz, hogy egy bajorországi szakakadémián elkezdjék tanulmányaikat, és akik az adott idegen nyelven Bajorországban letették a fordítók, illetve a fordítók és tolmácsok számára meghirdetett állami vizsgát" (SDI 2007: 1).

3. táblázat

Forditási/tolmácsolási BA-szakok a szakakadémiákon

\begin{tabular}{|l|l|l|l|}
\multicolumn{1}{c|}{ Szak } & \multicolumn{1}{|c|}{ Képző intézmény } & \multicolumn{1}{c|}{ Nyelvek } & \multicolumn{1}{c|}{$\begin{array}{c}\text { Képzés } \\
\text { helye }\end{array}$} \\
\hline $\begin{array}{l}\text { BA Szakfordítás } \\
\text { (Gazdasági/ } \\
\text { müszaki) }\end{array}$ & $\begin{array}{l}\text { A Fakultät für angewandte Natur- und } \\
\text { Geisteswissenschaften, Hochschule } \\
\text { für angewandte Wissenschaften } \\
\text { Würzburg-Schweinfurt (FHWS), } \\
\text { a WDS (Würzburg) és az ESO } \\
\text { (Bamberg) együttmüködésében }\end{array}$ & $\begin{array}{l}\text { angol, } \\
\text { francia, } \\
\text { német, } \\
\text { spanyol }\end{array}$ & Würzburg \\
\hline $\begin{array}{l}\text { Állami fordító- } \\
\text { és tolmácsvizsga } \\
\text { és BA Fordítás } \\
\text { (kettős végzettség) }\end{array}$ & $\begin{array}{l}\text { Az Internationale Hochschule SDI } \\
\text { München és az Institut für }\end{array}$ & $\begin{array}{l}\text { Fremdsprachen und Auslandskunde } \\
\text { Erlangen (IFA) együttmüködésében } \\
\text { francia, } \\
\text { német, } \\
\text { olasz, orosz, } \\
\text { spanyol }\end{array}$ & Erlangen \\
\hline $\begin{array}{l}\text { BA Fordítás } \\
\text { és állami vizsga }\end{array}$ & $\begin{array}{l}\text { Azz Internationale Hochschule SDI } \\
\text { München és az SDI }\end{array}$ & $\begin{array}{l}\text { angol, } \\
\text { együttmüködésében } \\
\text { fémet, } \\
\text { olasz, orosz, } \\
\text { spanyol }\end{array}$ & München \\
\hline
\end{tabular}

\subsubsection{Doktori képzés}

A doktori képzés ugyan nem a fordítók és tolmácsok szakmai képzésére irányul, azonban a fordítók/tolmácsok által megszerezhető felsőfokú végzettségek teljes spektrumának lefedése érdekében a vonatkozó doktori képzéseket is megemlítem:

- Rajnai Friedrich-Wilhelms-Egyetem Bonn, Bölcsészettudományi Kar. Doktori képzések: Fordítástudomány ${ }^{15}$ 
- Lipcsei Egyetem, Alkalmazott Nyelvészeti és Transzlatológiai Intézet. Doktori képzés: Alkalmazott Nyelvészet és Transzlatológia ${ }^{16}$

- Johannes Gutenberg-Egyetem Mainz, Transzláció-, Nyelv- és Kultúratudományi Egység. Doktori képzés: Általános transzlációtudomány

- Saar-vidéki Egyetem, Bölcsészettudományi Kar (nyelv-, irodalom- és kultúratudomány). Doktori képzések: Fordítás és tolmácsolás, Gépi fordítás, Nyelv- és transzlációtudomány ${ }^{17}$

\section{2. Állami vizsgák}

Amint az a 3.1.1-3.1.3. fejezetekből is kitünik, a német egyetemek fordító- és tolmácsképzési programja szükségszerüen csak néhány nyelvre terjed ki. Azok, akik egy ettől eltérő nyelvet beszélnek, vagy egy képzéstől független képesítésre törekszenek, egy országos szinten egységesen szabályozott fordító- és/vagy tolmácsvizsgát tehetnek. A vizsgára való felkészülés magánúton, a bajorországi szakakadémiákon meghirdetett hároméves fordító-/tolmácsképzés részeként vagy különféle, magánintézmények által kínált elökészítő tanfolyamok (távoktatás ${ }^{18}$, online tanfolyamok ${ }^{19}$ vagy személyes órák stb.) formájában zajlik. Az állami vizsga elöfeltétele általában a szakképesítés vagy a vonatkozó szakmai gyakorlat igazolása.

$\mathrm{Az}$,államilag vizsgáztatott fordítók/tolmácsok” (,staatlich geprüfter Übersetzer/Dolmetscher”) cím mellett gyakran találkozni az ,államilag elismert fordítók/tolmácsok” (,staatlich anerkannter Übersetzer/Dolmetscher”) titulussal is ${ }^{20}$ : A különbség az, hogy az első esetben a vizsgát közvetlenül a kormányhivatalnál (Regierungspräsidium) lehet letenni, az ,államilag elismert” vizsga esetében viszont egy államilag elismert (magánkézben lévő) oktatási intézményben kerül sor a vizsgára, minőségi és tartalmi különbség azonban nincs közöttük (lásd Pro $Z^{21}$ ).

A sikeres vizsga a fordítók és tolmácsok bíróság előtti felesketésének előfeltétele ${ }^{22}$, illetve a piacon minőségi garanciát, ennél fogva versenyelönyt jelent. A felesketéshez/felhatalmazáshoz azonban nem kell feltétlenül állami vizsgát tenni, tehát az erre irányuló kérelmet más végzettség birtokában is be lehet nyújtani (főleg, mivel a kisebb nyelvekből nem is lehet állami vizsgát tenni). A vizsga pontos felépítését a 2004. évi kulturális miniszteri konferencia határozata szabályozza, amely a fordító- és tolmácsvizsga lebonyolítására vonatkozó 1954-es irányelveket váltotta fel. ${ }^{23} \mathrm{~A}$ határozat föbb jellemzői a következők:

- A vizsgát általában évente egyszer lehet letenni.

- A vizsgát 1) fordítóknak, 2) tolmácsoknak, valamint 3) fordítóknak és tolmácsoknak hirdetik meg.

- A tartományok maguk dönthetnek arról, hogy a tolmácsvizsgát csak sikeres fordítóvizsga után lehet-e letenni (pl. Bajországban ez a jellemző).

- A fordítóvizsga írásbeli (öt részfeladat) és szóbeli részből (négy részfeladat) áll. A szóbeli vizsga időtartama otthoni feladatokkal vagy egy államilag 
elismert fordító- és/vagy tolmácsképzésben teljesített tanegységek beszámításával lerövidíthető. A tartományok vizsgaszabályzata további részfeladatokat is elöírhat. Az is a tartományok kompetenciája, hogy az írásbeli vizsga során engedélyeznek-e segédeszközöket.

- A tolmácsok vizsgája írásbeli részből (három részfeladat) és szóbeli részből (öt részfeladatból) áll.

- A sikeres vizsga az 1),„államilag vizsgáztatott fordító”, 2) „államilag vizsgáztatott tolmács” vagy 3), „államilag vizsgáztatott fordító és tolmács” cím használatára jogosít fel.

- A sikertelen vizsga csak egyszer ismételhetö.

A kulturális miniszteri konferencia rendelete értelmében a tartományok saját hatáskörben döntenek arról, hogy kívánnak-e létrehozni vizsgahelyet. Az alábbiakban bemutatom az egyes tartományok vizsgakínálatát, azonban fel kell hívni arra a figyelmet, hogy a vizsganyelvek és a választható szakterületek évröl évre változhatnak. Jelenleg az alábbi tartományokban nincs vizsgahely: Brandenburg, Bréma, Alsó-Szászország, Észak-Rajna-Vesztfália, Rajna-vidék-Pfalz, Schleswig-Holstein és Türingia. Ha egy tartományban nem müködik vizsgahely, vagy az adott nyelvből nem lehet vizsgát tenni, akkor egy másik tartományban is lehet vizsgára jelentkezni. A vizsgahelyek nemcsak a vizsgák lebonyolításáért felelnek, hanem szükség esetén a külföldön vagy egy más tartományban szerzett végzettségek vagy az ott letett vizsgák megfeleltetéséről is döntenek. Ugyanez igaz az állami vizsgákra is, tehát mielőtt valaki egy másik tartományban jelentkezik az állami vizsgára, érdemes utánajárnia, hogy a vizsgát elfogadják-e a lakóhelye szerinti tartományban.

Az állami vizsgák jogalapját az egyes szövetségi tartományok vonatkozó rendeletei képezik.

\section{4. táblázat}

Az egyes tartományok állami vizsgájának jogalapja

\begin{tabular}{|c|c|}
\hline Tartomány & Jogalap \\
\hline $\begin{array}{l}\text { Baden- } \\
\text { Württemberg }\end{array}$ & $\begin{array}{l}\text { A Kulturális Minisztérium rendelete a fordító- és tolmácsvizsgá- } \\
\text { ról, 1997. október } 21 .\end{array}$ \\
\hline & Fordítók és tolmácsok vizsgaszabályzata (ÜDPO), 2001. május 7. \\
\hline Bajorország ${ }^{24}$ & $\begin{array}{l}\text { Rendelet az államilag vizsgáztatott fordítók, tolmácsok vagy jel- } \\
\text { nyelvi tolmácsok képesítésének megfelelő külföldi szakképesítések } \\
\text { egyenrangúságának megállapításáról (BQFVÜDolm), 2008. már- } \\
\text { cius } 3 .\end{array}$ \\
\hline Berlin & Rendelet az állami fordítóvizsgáról, 1990. július 2. \\
\hline Hamburg & $\begin{array}{l}\text { Rendelet a hamburgi tolmácstörvény végrehajtásáról (Hamburgi } \\
\text { tolmácstörvény - HmbDolmVO), 2007. január } 23 .\end{array}$ \\
\hline
\end{tabular}




\begin{tabular}{|l|l|}
\hline \multirow{2}{*}{ Hessen } & $\begin{array}{l}\text { Rendelet a fordítók, tolmácsok és a német jelnyelvi (DGS) tanárok } \\
\text { hesseni állami vizsgájáról (ÜDPVO), 2018. január 16. }\end{array}$ \\
\hline \multirow{2}{*}{$\begin{array}{l}\text { Mecklenburg- } \\
\text { Elő-Pomeránia }\end{array}$} & $\begin{array}{l}\text { Rendelet a fordítók és tolmácsok vizsgájáról és a vizsgák elismeré- } \\
\text { sérôl a szakmai alkalmasság igazolásához, 2007. február 26. }\end{array}$ \\
\cline { 2 - 2 } & $\begin{array}{l}\text { Rendelet a tolmácsok és fordítók szakmai alkalmasságának igazo- } \\
\text { lásáról }\end{array}$ \\
\hline Saar-vidék & Rendelet a fordítók és tolmácsok állami vizsgájáról, 2018. április 16. \\
\hline Szászország & Szász tolmácsvizsga-rendelet, 2009. május 15. \\
\hline Szász-Anhalt & Tolmácsalkalmassági rendelet (DolmEigVO), 2010. június 11. \\
\hline
\end{tabular}

\section{Baden-Württemberg}

Baden-Württembergben a vizsga a karlsruhei kormányhivatal illetékessége. Vizsganyelvek: Német, angol, francia, hindi, pandzsábi, spanyol és urdu. Választható szakterületek: Humán tudományok, természettudományok, jog, társadalomtudományok, müszaki, gazdasági. ${ }^{25}$ Vizsgaévenként csak a felsorolt nyelvek egyikéből hirdetnek vizsgát.

\section{Bajorország}

Bajorországban a szakakadémiák által felkínált nyelvekből lehet állami vizsgát tenni (jelenleg angol, francia, spanyol, olasz és orosz nyelvböl), amelyet a szakakadémiák bonyolítanak le. Külső jelentkezöket is fogadnak, ha azok teljesítik az elöírt követelményeket.

Arab, kínai, dán, finn, horvát, holland, török nyelvböl a vizsgákat hároméves turnusban hirdetik meg a müncheni Oktatási és Kulturális Minisztériumban a fordítók és tolmácsok állami vizsgaközpontjában. ${ }^{26} \mathrm{Az}$ alábbi szakterületek közül lehet választani: Gazdaság, jog, müszaki, természettudományok (ideértve az orvostudományt), humán tudományok, társadalomtudományok. A vizsgát ugyanabban az időpontban két nyelvből vagy két szakterületböl is le lehet tenni (lásd a 2001. május 7-i vizsgaszabályzatot ${ }^{27}$ ).

Angol, francia, olasz, orosz és spanyol nyelvből évente szerveznek vizsgát a fordítók és tolmácsok különböző szakakadémiáin. Azok a hallgatók, akik sikeresen befejezték a szakakadémiát (lásd 3.1.3. fejezet), automatikusan jelentkeznek a fordítók és tolmácsok állami vizsgájára, és azon kötelező részt venniük.

Állami vizsgát jelenleg az alábbi nyolc szakakadémián lehet tenni. ${ }^{28}$ 
5. táblázat

Állami vizsgák a szakakadémiákon

\begin{tabular}{|l|l|l|l|}
\hline \multicolumn{1}{|c|}{ Szakakadémia } & \multicolumn{1}{|c|}{ Nyelvek } & \multicolumn{1}{|c|}{ Szakterületek } & Vizsgahely \\
\hline $\begin{array}{l}\text { Euro Akademie } \\
\text { Bamberg (ESO) }\end{array}$ & angol & gazdaság & Bamberg \\
\hline EURO Schulverein & angol & gazdaság & Ingolstadt \\
\hline Europa-Berufsschule & angol & gazdaság & Weiden \\
\hline $\begin{array}{l}\text { Müncheni Idegen } \\
\text { Nyelvi Intézet (FIM) }\end{array}$ & $\begin{array}{l}\text { angol, } \\
\text { francia, } \\
\text { spanyol }\end{array}$ & $\begin{array}{l}\text { gazdaság (összes nyelv), } \\
\text { müszaki (angol, spanyol) }\end{array}$ & München \\
\hline $\begin{array}{l}\text { IFB Idegen Nyelvi } \\
\text { Szakmák Intézete }\end{array}$ & angol & gazdaság & Kempten \\
\hline $\begin{array}{l}\text { Idegen Nyelvi és } \\
\text { Nemzetközi } \\
\text { Tanulmányok } \\
\text { Intézete (IFA) }\end{array}$ & $\begin{array}{l}\text { angol, } \\
\text { francia, } \\
\text { orosz, } \\
\text { spanyol }\end{array}$ & $\begin{array}{l}\text { gazdaság (összes nyelv), } \\
\text { müszaki (összes nyelv) humán } \\
\text { tudományok (angol, spanyol), } \\
\text { jog (angol) }\end{array}$ & Erlangen \\
\hline $\begin{array}{l}\text { Müncheni Nyelvi és } \\
\text { Tolmácsintézet (SDI) }\end{array}$ & $\begin{array}{l}\text { angol, } \\
\text { francia, } \\
\text { olasz, orosz, } \\
\text { spanyol }\end{array}$ & $\begin{array}{l}\text { gazdaság (összes nyelv), } \\
\text { müszaki (angol, orosz, } \\
\text { spanyol), jog (angol, francia, } \\
\text { olasz), természettudományok } \\
\text { (angol) }\end{array}$ & München \\
\hline $\begin{array}{l}\text { Würzburgi } \\
\text { Tolmácsiskola (WDS) }\end{array}$ & $\begin{array}{l}\text { gazdaság, } \\
\text { természettudományok }\end{array}$ & Würzburg \\
\hline
\end{tabular}

\section{Berlin}

Berlinben az Oktatási, Ifjúsági és Családügyi Minisztérium (Szenátus) állami fordítói vizsgahelyén lehet vizsgát tenni az alábbi nyelvekből: Arab (AR), bolgár (BG), kínai (CN), angol (GB), francia (FR), olasz (IT), japán (JA), újgörög (NG), lengyel (PL), portugál (PG), orosz (RU), szlovák (SL), spanyol (SP), cseh (CZ), török (TR), magyar (HU). Szakterületek: Humán tudományok (összes nyelv), társadalomtudományok (összes nyelv, kivéve TR), természettudományok (AR, GB, PG), müszaki (AR, GB, SP), jog (AR, GB, HU, PL, PG, RU), gazdaság (AR, CN, CZ, FR, GB, HU, JA, PL, RU, SL, SP).

\section{Hamburg}

Hamburgban a fordító- és tolmácsvizsga (az ún. alkalmassági eljárás) az általánosan felesketett tolmácsok és/vagy fordítók kirendelésére szolgál, ezért nem jogosít fel az ,államilag vizsgáztatott fordító és/vagy tolmács” cím használatára. Mivel 
azonban a vizsga tartalmi szempontból megegyezik a többi tartomány állami vizsgájával, célszerü itt bemutatni. A vizsga a Belügyi és Sporthivatal Belső Igazgatási és Tervezési Irodájának a hatáskörébe tartozik (általános politikai és jogi kérdések, tolmácsok és fordítók felesketése), jogalapként pedig a tolmácsok és fordítók kirendelésére és felesketésére vonatkozó törvény szolgál (lásd a 4. fejezetet). Legalább három jelentkező esetén minden nyelvböl lehet vizsgát tenni (a ritka nyelveknél ettől kevesebb jelentkező esetén is hirdetnek vizsgát), és mivel a vizsga az általánosan felesketett tolmácsok és/vagy fordítók kirendelésére irányul, a jogi szaknyelv kapja a fó hangsúlyt.

\section{Hessen}

Hessenben a Kulturális Minisztériumnak alárendelt Hesseni Tanári Akadémia (Darmstadt) hatáskörébe tartozik az állami vizsga. Itt számos nyelv közül lehet választani: Albán, amhara, arab, örmény, bosnyák, kínai, dari, angol, észt, francia, grúz, indonéz, olasz, japán, koreai, horvát, kurmandzsi, litván, macedón, újgörög, pastu, perzsa, lengyel, portugál, román, orosz, szerb, szlovák, szlovén, spanyol, thai, cseh, török, magyar, ukrán. Szakterületek: Humán tudományok, természettudományok, jog, társadalomtudományok, müszaki, gazdaság és egészségügy. Sok nyelv esetében vagy megfelelő számú vizsgázó esetén a vizsgákat - a legtöbb vizsgahellyel ellentétben - évente kétszer is meghirdetik.

Ezenkívül az ún. ellenőrzési eljárás keretében az összes olyan ritkább nyelvből vagy dialektusból is lehet vizsgázni, amelyekből Németországban egyébként nem szerveznek állami vizsgát. Az ellenőrzési eljárást nem egy elöre meghatározott időpontban hirdetik meg (egyébként általában évente egyszer lehet ilyen vizsgát tenni), és bármikor lehet rá jelentkezni. Sikeres vizsga esetén egy igazolást állítanak ki, amely azonban érvényét veszti, ha „Németország valamelyik tartományában az adott nyelvböl létrehoznak egy állami vizsgahelyet". ${ }^{29}$

\section{Mecklenburg-Elö-Pomeránia}

Mecklenburg-Elö-Pomerániában a fordítók és tolmácsok vizsgahivatala illetékes a vizsgával kapcsolatos kérdésekben, amely az Oktatási, Tudományos és Kulturális Minisztérium (Rostock) tanári vizsgahelye alá tartozik. A vizsgát angol, finn, francia, lengyel, orosz, svéd, spanyol nyelven, valamint gazdasági, jogi, müszaki, természettudományi, humán és társadalomtudományi szakterületen lehet letenni.

\section{Saar-vidék}

A vizsga lebonyolításáért az Oktatási és Kulturális Minisztériumhoz tartozó Iskolai Oktatási Vizsgahivatal, azon belül az államilag vizsgáztatott fordítók és tolmácsok vizsgaközpontja (Saarbrücken) felel. Az alábbi nyelvekből és szakterületeken lehet vizsgát tenni: Angol, francia, olasz, orosz, spanyol, török; gazdaság (összes nyelv), társadalomtudományok (francia, spanyol), müszaki (orosz, török), jog (török). 


\section{Szászország}

Szászországban az állami vizsga lebonyolítását az Iskolai és Oktatási Hivatal (Lipcse) koordinálja. Vizsgát az alábbi nyelvekböl lehet tenni: Arab, bosnyák, bolgár, kínai, angol, francia, olasz, horvát, lengyel, román, orosz, szerb, spanyol, cseh, ukrán, magyar, vietnami, azonban időpontot csak megfelelö számú jelentkező és megfelelően képesített vizsgáztatók esetén hirdetnek meg. Szakterületek: Humán tudományok, természettudományok (ideértve az orvostudományt), jog, társadalomtudományok, müszaki, gazdaság.

\section{Szász-Anhalt}

Szász-Anhaltban, hasonlóan Hamburghoz, a jelöltek szakmai alkalmasságának megállapítására szolgáló eljáráson kell részt venni, ami a fordítók és tolmácsok felesketésére és kirendelésére szolgál. Az alkalmassági eljárást a Szász-Anhalti Iskolai Hivatal Magdeburgi Kirendeltsége szervezi meg. A szakmai alkalmasság megállapítása után az erre jogosult fordítók és tolmácsok az „államilag elismert fordító”, ,államilag elismert tolmács” vagy az ,államilag elismert fordító és tolmács" címet használhatják.

\subsection{A kereskedelmi és iparkamarák vizsgái}

Ha egy tartományban az állami vizsgáztatásnak nincs vizsgaközpontja, akkor az Ipari és Kereskedelmi Kamaráknál (IHK) is lehet vizsgát tenni. Az állami vizsgával ellentétben azonban a sikeres IHK-vizsgával nem teljesülnek a felhatalmazáshoz/felesketéshez szükséges feltételek, mivel nem államilag elismert vizsgáról van szó (ez alól pl. Észak-Rajna-Vesztfália kivétel ${ }^{30}$ ). Az IHK-t egyébként a 2005. március 23-i szakképzési törvény $§ 71$ (2) pontja ruházza fel a szakképzési és továbbképzési területen való vizsgáztatás jogával. A vizsgával általában a „,vizsgáztatott fordító" képesítést lehet megszerezni, és elsődleges célcsoportját azok alkotják, akik valamilyen kapcsolódó területen dolgoznak (lektorként, újságíróként, idegen nyelvi levelezőként stb.), a különféle szövegekkel kapcsolatban már van vonatkozó munkatapasztalatuk, és biztos idegennyelv-tudással rendelkeznek. A jelölteknek a vizsgára való jelentkezéshez a szakmai végzettségüket, egyéves szakmai tapasztalatot és/vagy az idegen nyelvi, fordításmódszertani és gazdasági ismereteik meglétét kell igazolniuk (Fordítóvizsgáztatási rendelet §3 (1)).

A ,vizsgázott tolmács" vizsga, amelyet az Oktatási és Kutatási Minisztérium 2004. május 18-i rendeletével vezetett be, az új fordítóvizsgáztatási rendelet 2018. január 1-jei hatályba lépése ${ }^{31}$ óta már nem tehető le. A Németországban található 79 IHK-kirendeltség közül csak Berlinben (angol), Düsseldorfban (német, angol, francia, olasz, orosz), Kölnben (angol) és Wiesbadenben (angol) lehet vizsgát tenni, máshol kevés jelentkező esetén nem, vagy csak szükség esetén szerveznek vizsgát. ${ }^{32}$

A fent említett, 2017. május 8-i rendelettel a vizsgázott fordítókra vonatkozó vizsgát teljesen átszervezték, hogy jobban megfeleljen a fordítóipari piac és a di- 
gitális világ jelenlegi követelményeinek. Az új rendelettel átalakított vizsga, amelyre 2019 tavasza óta lehet jelentkezni, egy írásbeli részből, valamint egy fordítási projektből áll, amely egy szakmai vitával zárul (vö. Reinecke 2017a és 2017b). Az írásbeli rész három feladatból tevődik össze:

(1) egy kb. 1200 karakterből álló nehéz szöveg lefordítása németről idegen nyelvre,

(2) egy kb. 1200 karakterből álló nehéz szöveg lefordítása idegen nyelvről németre,

(3) egy nehéz idegen nyelvű szöveg összefoglalása idegen nyelven és egy német nyelvű fordítás javítása nyelvhelyességi és stilisztikai szempontból.

Az írásbeli rész teljesítésére összesen 240 perc áll rendelkezésre. A fordítási projektet az írásbeli vizsga eredményének közzétételétől számított két éven belül kell megvalósítani. A vizsgára jelentkező személynek azt kell bebizonyítania, hogy képes végrehajtani egy fordítási megbízást, elemezni az ügyfelek igényeit, valamint megfelelő eszközöket és információforrásokat használ. A fordítási projekt a következő feladatokból áll:

(1) egy körülbelül 1800 karakter hosszúságú szöveg fordítása idegen nyelvről német nyelvre,

(2) otthoni feladat elkészítése idegen nyelven (feldolgozási idő 14 naptári nap), amelyben a jelöltnek kommentálnia és dokumentálnia kell az első feladat lépéseit és döntéseit,

(3) a szakmai vitára a projekt befejezése után kerül sor, és a vizsgázónak be kell bizonyítania, hogy az adott idegen nyelven képes magas szinten megfogalmazni a gondolatait a fordítási gyakorlat különféle szempontjairól és az adott szakterületről (időtartam: legfeljebb 45 perc).

Az IHK-vizsgákon természetesen a gazdasági szakterület (bank és pénzügyek, üzleti adminisztráció, nemzetgazdaság, nemzetközi kereskedelem, információs és telekommunikációs technológiák stb.) kapja a legnagyobb hangsúlyt, azonban a gazdasági szövegek olykor jogi vagy politikai vonatkozásúak is lehetnek. A vizsgát kétszer lehet megismételni.

\section{Felesketés, felhatalmazás}

A felesketés (Vereidigung) és a - magyarul elég sután hangzó - felhatalmazás (Ermächtigung), Németország 16 tartományában eltérően szabályozott intézményét a hatósági, bírósági vagy egyéb hivatalos dokumentumok fordításához, valamint a hatóságok és a bíróságok számára történő tolmácsoláshoz vezették be. A felesketett és felhatalmazott tolmácsok és fordítók esetében használt (és a laikusok 
számára nagyon zavaró) fogalmi sokszínüség részben hasonló tartalmi elemeket takar, és az egyes tartományok eltérő jogi nyelvhasználatából ered.

\section{6. táblázat \\ A felesketett és felhatalmazott forditók és tolmácsok elnevezése az egyes tartományokban}

\begin{tabular}{|c|c|c|}
\hline Tartomány & Tolmácsok elnevezése & Fordítók elnevezése \\
\hline $\begin{array}{l}\text { Baden- } \\
\text { Württemberg }\end{array}$ & $\begin{array}{l}\text { Baden-Württemberg tartomány } \\
\text { bíróságainak ... nyelvre általáno- } \\
\text { san felesketett tárgyalási tolmácsa }\end{array}$ & $\begin{array}{l}\text { Baden-Württemberg ... nyelven } \\
\text { nyilvánosan kirendelt és feleske- } \\
\text { tett okiratfordítója }\end{array}$ \\
\hline Bajorország & $\begin{array}{l}\text { nyilvánosan kirendelt és feleske- } \\
\text { tett tolmács ... nyelven }\end{array}$ & $\begin{array}{l}\text { nyilvánosan kirendelt és feleske- } \\
\text { tett fordító ... nyelven }\end{array}$ \\
\hline Berlin & $\begin{array}{l}\text { a berlini bíróságokhoz és közjegy- } \\
\text { zőkhöz általánosan felesketett } \\
\text { tolmács }\end{array}$ & $\begin{array}{l}\text { a berlini bíróságokhoz és közjegy- } \\
\text { zőkhöz felhatalmazott fordító }\end{array}$ \\
\hline Branc & $\begin{array}{l}\text { A ... járásbíróság elnöke által } \\
\text { általánosan felesketett tolmács és } \\
\text { felhatalmazott fordító ... nyelven }\end{array}$ & $\begin{array}{l}\text { A . . járásbíróság elnöke által } \\
\text { általánosan felhatalmazott fordító } \\
\text {... nyelven }\end{array}$ \\
\hline Bréma & $\begin{array}{l}\text { Bréma mint szabad Hanza-város } \\
\text { bíróságaihoz, ügyészségéhez és } \\
\text { közjegyzőihez általánosan feles- } \\
\text { ketett tolmács ... nyelven }\end{array}$ & $\begin{array}{l}\text { Bréma mint szabad Hanza-város } \\
\text { bíróságaihoz, ügyészségéhez és } \\
\text { közjegyzőihez a brémai járási } \\
\text { bíróság elnöke által felhatalma- } \\
\text { zott fordító ... nyelven }\end{array}$ \\
\hline Hamburg & $\begin{array}{l}\text { nyilvánosan kirendelt } \\
\text { san felesketett tolmács }\end{array}$ & $\begin{array}{l}\text { nyilvánosan kirendelt és általáno- } \\
\text { san felesketett fordító ... nyelven }\end{array}$ \\
\hline Hessen & $\begin{array}{l}\text { általánosan felesketett tolmács (a } \\
\text { nyelvvel kiegészítve) }\end{array}$ & $\begin{array}{l}\text { általánosan felhatalmazott fordító } \\
\text { (a nyelvvel kiegészítve) }\end{array}$ \\
\hline $\begin{array}{l}\text { Mecklenburg- } \\
\text { Elö-Pomeránia }\end{array}$ & $\begin{array}{l}\text { nyilvánosan kirendelt és általáno- } \\
\text { san felesketett tolmács ... nyelven }\end{array}$ & $\begin{array}{l}\text { nyilvánosan kirendelt és általáno- } \\
\text { san felesketett fordító ... nyelven }\end{array}$ \\
\hline $\begin{array}{l}\text { Alsó- } \\
\text { Szászország }\end{array}$ & $\begin{array}{l}\text { a hannoveri járási bíróság által } \\
\text { általánosan felesketett tolmács ... } \\
\text { nyelven }\end{array}$ & $\begin{array}{l}\text { a hannoveri járási bíróság által } \\
\text { felhatalmazott fordító ... nyelven }\end{array}$ \\
\hline $\begin{array}{l}\text { Észak-Rajna- } \\
\text { Vesztfália }\end{array}$ & $\begin{array}{l}\text { általánosan felesketett tolmács ... } \\
\text { nyelven }\end{array}$ & $\begin{array}{l}\text { a ... tartományi legfelsőbb bíró- } \\
\text { ság elnöke által felhatalmazott } \\
\text { fordító ... nyelven }\end{array}$ \\
\hline
\end{tabular}




\begin{tabular}{|c|c|c|}
\hline Tarto & Tolmácsok e & Fordítók elnevezése \\
\hline $\begin{array}{l}\text { Rajna-vidék- } \\
\text { Pfalz }\end{array}$ & $\begin{array}{l}\text { a ... tartományi legfelsőbb bíró- } \\
\text { ság elnöke által a Rajna-vidék- } \\
\text { pfalzi bírósági és közjegyzői } \\
\text { ügyekhez általánosan felesketett } \\
\text { tolmács ... nyelven }\end{array}$ & $\begin{array}{l}\text { a ... tartományi legfelsőbb bíró- } \\
\text { ság elnöke által a Rajna-vidék- } \\
\text { pfalzi bírósági ügyekhez felhatal- } \\
\text { mazott fordító ... nyelven }\end{array}$ \\
\hline Saar & $\begin{array}{l}\text { a Saar-vidéki bíróságokhoz és } \\
\text { közjegyzökhöz általánosan feles- } \\
\text { ketett tolmács }\end{array}$ & $\begin{array}{l}\text { a Saar-vidéki bíróságokhoz és } \\
\text { közjegyzőkhöz általánosan feles- } \\
\text { ketett fordító }\end{array}$ \\
\hline Szász & $\begin{array}{l}\text { nyilvánosan kirendelt és általáno- } \\
\text { san felesketett tolmács ... nyelven }\end{array}$ & $\begin{array}{l}\text { nyilvánosan } \\
\text { san feleskete }\end{array}$ \\
\hline Szász & $\begin{array}{l}\text { általánosan kire } \\
\text { nyelvvel kiegés }\end{array}$ & $\begin{array}{l}\text { általánosan } \mathrm{k} \\
\text { nyelvvel kieg }\end{array}$ \\
\hline $\begin{array}{l}\text { Schleswig- } \\
\text { Holstein }\end{array}$ & $\begin{array}{l}\text { Schleswig-Holstein tartomány } \\
\text { bíróságaihoz és ügyészségeihez } \\
\text { általánosan felesketett tolmács ... } \\
\text { nyelven }\end{array}$ & $\begin{array}{l}\text { Schleswig-Holstein tartomány } \\
\text { bíróságaihoz és ügyészségeihez } \\
\text { felhatalmazott fordító ... nyelven }\end{array}$ \\
\hline Tür & $\begin{array}{l}\text { a ... járásbíróság elnöke által a } \\
\text { bíróságokhoz, ügyészségekhez és } \\
\text { közjegyzőkhöz általánosan feles- } \\
\text { ketett tolmács ... nyelven }\end{array}$ & $\begin{array}{l}\text { a ... járásbíróság elnöke által a } \\
\text { bíróságokhoz, ügyészségekhez és } \\
\text { közjegyzőkhöz felhatalmazott } \\
\text { fordító ... nyelven }\end{array}$ \\
\hline
\end{tabular}

A felesketés előnye többek között az, hogy a tolmácsnak a bírósági eljárásban elegendő az esküre hivatkoznia (vö. Horváth 2017: 183), míg egy nem felesketett tolmácsnak a bíróságok szervezetéröl szóló törvény (GVG) § 189 (1) értelmében elöször le kell tennie az esküt, miszerint pontosan és lelkiismeretesen fogja fordítani az elhangzottakat. Ezt az esküt minden eljárásnál meg kell ismételni. Mivel a felesketés minőségi mutatónak is számít, a bíróságok általában felesketett tolmácsokat alkalmaznak.

A tolmácsok alkalmazásának megkönnyítése érdekében a felesketett tolmácsok és a felhatalmazott fordítók adatait (a bérmegállapodások kivételével) az írásbeli beleegyezésük után az illetékes hatóság (járásbíróság, tartományi legfelsőbb bíróság) egy mindenki által megtekinthető listán rögzíti, amelyet általában a hatóság honlapján is közzétesznek. Ezenkívül egy országos lefedettségü online adatbank is létezik ${ }^{33}$, amelyet a hesseni igazságügyi minisztérium kezel, és amely az összes, Németországban felesketett és felhatalmazott tolmács és fordító adatait tartalmazza (növekvő tendencia mellett jelenleg mintegy 25000 bejegyzés található az adatbázisban, 1. a 7. táblázatot). Horváth (2017: 184) ezzel kapcsolatban megjegyzi, hogy a bíróságok által kezelt listák nem minden esetben egyeznek meg az online adatbázissal. 


\section{7. táblázat}

A felesketett és felhatalmazott tolmácsok és forditók száma tartományonként

\begin{tabular}{|l|c|c|}
\hline & 2018.11.20-i állapot & 2020.02.09-i állapot \\
\hline Bajorország & 4976 & 5086 \\
\hline Baden-Württemberg & 4881 & 4859 \\
\hline Hessen & 2818 & 2852 \\
\hline Észak-Rajna-Vesztfália & 2742 & 2851 \\
\hline Berlin & 1831 & 1873 \\
\hline Rajna-vidék-Pfalz & 1337 & 1383 \\
\hline Szászország & 1105 & 1144 \\
\hline Saar-vidék & 1103 & 1124 \\
\hline Alsó-Szászország & 981 & 1042 \\
\hline Schleswig-Holstein & 908 & 938 \\
\hline Türingia & 361 & 365 \\
\hline Szász-Anhalt & 339 & 346 \\
\hline Brandenburg & 319 & 342 \\
\hline Hamburg & 290 & 290 \\
\hline Bréma & 127 & 159 \\
\hline Mecklenburg-Elö-Pomeránia & 103 & 110 \\
\hline Összesen & 24221 & 24764 \\
\hline
\end{tabular}

(Forrás: http://www.justiz-dolmetscher.de)

A felhatalmazás révén a fordítók jogosulttá válnak arra, hogy igazolják egy fordítás helyességét és teljességét, ha a bíróság a polgári perrendtartás (ZPO) § 142 (3) értelmében egy felhatalmazott fordító által készített fordítást kér egy idegen nyelvủ okiratról. Az ily módon elkészült és igazolt (a köznyelvben „,hitelesített fordítás” néven is ismert) fordítást egy hitelesítési záradékkal kell ellátni, amelyben a fordítás helyességét és teljességét a fordító az aláírásával (vagy - ha a törvény lehetőséget ad rá - hiteles elektronikus aláírással), valamint a hely és idő feltüntetésével, esetleg a pecsétjével igazol (utóbbira akkor van szükség, ha az adott tartomány elöírja a pecsét használatát). Néhány tartományban (Bajorország, Bréma stb.) azt is fel kell tüntetni a hitelesített fordításon, hogy az az eredetiről, az eredeti hiteles másolatáról vagy pedig az eredeti nem hitelesített másolatáról készült. A hitelesítés módját több tartományban (Bajorországban, Hamburgban, Mecklenburg-Elö- 
Pomerániában, Alsó-Szászországban stb.) az adott tolmácstörvény szabályozza. A hitelesített fordítások tipográfiai és egyéb formai követelményeit (íráskép, megjegyzések, az eredetiben lévő gépelési hibák kezelése stb.) a bíróságok által kiadott tájékoztatók és a szakmai szervezetek ajánlásai tartalmazzák (vö. Cebulla 2012: 292 is). Fontos hangsúlyozni, hogy még a hitelesített fordítás sem minősül közokiratnak, és hogy az elnevezések közötti különbségek ellenére a hitelesített fordítás 2008 óta a polgári perrendtartás (ZPO) § 142 (3) értelmében minden tartományban érvényes, függetlenül attól, hogy a fordítást melyik tartományban készítették, vagy hogy a fordító hol kapott felhatalmazást:

A bíróság elrendelheti, hogy egy idegen nyelven írt okiratot olyan fordító fordítson le egy másik nyelvre, akit az adott tartomány jogi elóírásai szerint felhatalmaztak vagy nyilvánosan kirendeltek egy ilyen jellegü fordítás elkészítésére, vagy aki egyenrangúnak tekinthető egy ilyen fordítóval. ${ }^{34}$

A felesketett és felhatalmazott fordítók és tolmácsok érdekeit az öt németországi szakmai szervezetből összeálló Igazságügyi Tolmácsok és Fordítók Országos Fóruma $(\mathrm{BFJ})$ és több tartományi szervezet képviseli.

8. táblázat

A felesketett és felhatalmazott forditók és tolmácsok szakmai szervezetei az egyes tartományokban

\begin{tabular}{|l|l|c|}
\hline \multicolumn{1}{|c|}{ Tartomány } & \multicolumn{1}{|c|}{ Szervezet } & $\begin{array}{c}\text { Alapítás } \\
\text { éve }\end{array}$ \\
\hline $\begin{array}{l}\text { Baden- } \\
\text { Württemberg }\end{array}$ & $\begin{array}{l}\text { Baden-württembergi felesketett tárgyalási tolmácsok és } \\
\text { nyilvánosan kirendelt és felesketett okiratfordítók szövetsége }\end{array}$ & 1971 \\
\hline Bajorország & $\begin{array}{l}\text { Bajorországi nyilvánosan kirendelt és felesketett tolmácsok } \\
\text { és fordítók egyesülete }\end{array}$ & 2002 \\
\hline Hamburg & Hamburgi felesketett tolmácsok és fordítók egyesülete & 1981 \\
\hline Hessen & Hesseni felesketett bírósági tolmácsok és fordítók & 2005 \\
\hline Szászország & Szászországi felesketett tolmácsok és fordítók egyesülete & 2000 \\
\hline
\end{tabular}

A felesketési vagy a felhatalmazási eljárás a személyes és szakmai alkalmasságot igazoló írásbeli kérelem alapján indítható el, amelyet az illetékes járásbírósághoz vagy a tartományi legfelsőbb bírósághoz való benyújtás után három hónapon belül bírálnak el. Ha valaki tolmácsként és fordítóként is kérelmezi a felesketést, ill. a felhatalmazást, annak két külön kérelmet kell benyújtania (feltéve, hogy az adott tartományban különbséget tesznek tolmácsok és fordítók között). Pozitív döntés esetén kitúznek egy időpontot, amikor sor kerül a felesketésre, illetve a felhatalmazási igazolás kézbesítésére. Néhány tartományban nemcsak a tolmácsoknak, 
hanem a fordítóknak is kell esküt tenniük (erre utal a „felesketett fordító” kifejezés). Ha azonban valaki vallási vagy lelkiismereti okok miatt nem akar esküt tenni, annak fogadalmat (Bekräftigung) kell tennie. Észak-Rajna-Vesztfáliában a felesketésre vagy a felhatalmazásra való hivatkozás joga visszavonhatóan legfeljebb öt évre szól (tehát ennyi ideig nincs szükség újabb felesketési vagy felhatalmazási eljárásra), és legfeljebb öt-öt évvel meghosszabbítható, a többi tartományban a fordítók/tolmácsok határozatlan idöre kapják ezt a jogot.

A 6. sz. táblázatban szereplő terminológiai zürzavart tovább növeli a „nyilvánosan kirendelt tolmács” és a „nyilvánosan kirendelt fordító” megjelölés, amelyet hat tartományban (Bajorország, Hamburg, Mecklenburg-Elő-Pomeránia, Szászország, Szász-Anhalt, Baden-Württembergben, illetve itt csak a „nyilvánosan kirendelt fordító" használatos) lehet megszerezni. Ma ezek a kifejezések már egyenértéküek az ,általánosan felesketett”, ,általánosan felhatalmazott” stb. elnevezésekkel, azonban néhány tartomány ( $\mathrm{pl}$. Rajna-vidék-Pfalz, Saar-vidék) tolmácstörvénye kimondja, hogy a felesketés nem jelent egyúttal nyilvános kirendelést (lásd Rüger 2010: 77 is).

A Szövetségi Közigazgatási Bíróság 2007-es döntése óta a tolmácsok és fordítók felesketésére, felhatalmazására és kirendelésére csak törvény útján kerülhet sor. Az ehhez szükséges jogalapot a bíróságok szervezetéről szóló törvény végrehajtási törvényei vagy a tartományok saját tolmácstörvényei biztosítják (Bréma volt az utolsó olyan tartomány, amely 2014-ben egy vonatkozó bekezdéssel kiegészítette a bíróságok szervezetéről szóló törvényt).

\section{9. táblázat}

A tolmácsok és forditók felesketésének és felhatalmazásának jogalapja tartományonként

\begin{tabular}{|c|c|c|c|}
\hline Tartomány & Jogalap & Rövidítés & $\begin{array}{l}\text { Hatályba } \\
\text { lépés }\end{array}$ \\
\hline $\begin{array}{l}\text { Baden- } \\
\text { Württemberg }\end{array}$ & $\begin{array}{l}\text { A bíróságok szervezetéről szóló törvény és } \\
\text { a rendes joghatósággal rendelkező eljárási } \\
\text { törvények végrehajtási törvénye (ötödik } \\
\text { szakasz, §14-§15b) }\end{array}$ & AGGVG & 1976 \\
\hline \multirow{2}{*}{ Bajorország } & $\begin{array}{l}\text { A tolmácsok és fordítók nyilvános kirende- } \\
\text { léséről és általános felesketéséröl szóló tör- } \\
\text { vény (tolmácstörvény) }\end{array}$ & DolmG BY & $\begin{array}{l}1953 \\
(1981)\end{array}$ \\
\hline & $\begin{array}{l}\text { A tolmácstörvény végrehajtása; tolmácsok } \\
\text { és fordítók nyilvános kirendelése és általá- } \\
\text { nos felesketése }\end{array}$ & DolmG-V & 2015 \\
\hline Berlin & $\begin{array}{l}\text { A bíróságok szervezetéről szóló törvény } \\
\text { végrehajtási törvénye (§19) }\end{array}$ & AGGVG & 1992 \\
\hline
\end{tabular}




\begin{tabular}{|c|c|c|c|}
\hline Tartomány & Jogalap & Rövidítés & $\begin{array}{l}\text { Hatályba } \\
\text { lépés }\end{array}$ \\
\hline Berlin & $\begin{array}{l}\text { A tolmácsok általános felesketéséről és a } \\
\text { fordítók felhatalmazásáról szóló rendelet }\end{array}$ & DolmV BE & 2010 \\
\hline Brandenburg & $\begin{array}{l}\text { A tolmácsok általános felesketéséről és a } \\
\text { fordítók felhatalmazásáról szóló Branden- } \\
\text { burg tartományi törvény (brandenburgi } \\
\text { tolmácstörvény) }\end{array}$ & BbgDolmG & 2009 \\
\hline Bréma & $\begin{array}{l}\text { A bíróságok szervezetéről szóló törvény } \\
\text { végrehajtására vonatkozó törvény (6. sza- } \\
\text { kasz } 28 \mathrm{a}-\$ 28 k \text {, hozzáadva } 2014 \text { novem- } \\
\text { berében) }\end{array}$ & AGGVG & $\begin{array}{c}1960 \\
(2014)\end{array}$ \\
\hline \multirow[t]{2}{*}{ Hamburg } & $\begin{array}{l}\text { A tolmácsok és fordítók nyilvános kirende- } \\
\text { léséről és általános felesketéséről szóló tör- } \\
\text { vény (tolmácstörvény) }\end{array}$ & HmbDolmG & 2005 \\
\hline & $\begin{array}{l}\text { Rendelet a hamburgi tolmácstörvény végre- } \\
\text { hajtásáról }\end{array}$ & HmbDolmVO & 2007 \\
\hline Hessen & Hesseni tolmács- és fordítótörvény & DolmG HE & 2010 \\
\hline $\begin{array}{l}\text { Mecklenburg- } \\
\text { Elö-Pomerá- } \\
\text { nia }\end{array}$ & $\begin{array}{l}\text { A tolmácsok és fordítók nyilvános kirende- } \\
\text { léséről és általános felesketéséről szóló tör- } \\
\text { vény (tolmácstörvény) }\end{array}$ & DolmG M-V & 1993 \\
\hline $\begin{array}{l}\text { Alsó-Szász- } \\
\text { ország }\end{array}$ & $\begin{array}{l}\text { Alsó-szászországi igazságügyi törvény } \\
\text { (ötödik fejezet §22-§31) }\end{array}$ & NJG & 2014 \\
\hline $\begin{array}{l}\text { Észak-Rajna- } \\
\text { Vesztfália }\end{array}$ & $\begin{array}{l}\text { A tolmácsokról és fordítókról, valamint az } \\
\text { Észak-Rajna-Vesztfália igazságszolgáltatási } \\
\text { rendszerében keletkezett iratok tárolásáról } \\
\text { szóló törvény }\end{array}$ & & 2008 \\
\hline $\begin{array}{l}\text { Rajna-vidék- } \\
\text { Pfalz }\end{array}$ & $\begin{array}{l}\text { Tartományi törvény az igazságszolgáltatás- } \\
\text { ban dolgozó tolmácsokról és fordítókról }\end{array}$ & LDÜJG & 2008 \\
\hline Saar-vidék & $\begin{array}{l}\text { Saar-vidéki törvény a bíróságok szervezeté- } \\
\text { rôl szóló törvény végrehajtásáról }\end{array}$ & SAG GVG & 1973 \\
\hline \multirow{3}{*}{ Szászország } & Szászországi tolmácstörvény & SächsDolmG & 2008 \\
\hline & Szászországi tolmácsrendelet & SächsDolmVO & 2008 \\
\hline & $\begin{array}{l}\text { A szász igazságügyi minisztérium közigaz- } \\
\text { gatási rendelete a szász tolmácstörvényröl }\end{array}$ & $\begin{array}{l}\text { VwV Dol- } \\
\text { metscher }\end{array}$ & 2008 \\
\hline Szász-Anhalt & Szász-Anhalt tartomány tolmácstörvénye & DolmG LSA & 2009 \\
\hline
\end{tabular}




\begin{tabular}{|l|l|l|c|}
\hline \multicolumn{1}{|c|}{ Tartomány } & \multicolumn{1}{|c|}{ Jogalap } & Rövidítés & $\begin{array}{c}\text { Hatályba } \\
\text { lépés }\end{array}$ \\
\hline $\begin{array}{l}\text { Schleswig- } \\
\text { Holstein }\end{array}$ & $\begin{array}{l}\text { Tartományi igazságügyi törvény (10. rész } \\
\S 74-\S 83)\end{array}$ & LJG & 2018 \\
\hline Türingia & $\begin{array}{l}\text { Türingiai törvény a bíróságok szervezetéröl } \\
\text { zzóló törvény végrehajtásáról (ötödik sza- } \\
\text { kasz §15-§24) }\end{array}$ & ThürAGGVG & 1993 \\
\hline
\end{tabular}

A felesketésre és a felhatalmazásra vonatkozó követelményeket a tartományok vonatkozó tolmácstörvényei szabályozzák. Általános követelmény a személyes megbízhatóság, a cselekvőképesség és a szakmai alkalmasság, amit egy sikeresen elvégzett egyetemi képzés, egy tolmács- vagy fordítói vizsga vagy egy azzal egyenértéküként elismert vizsga formájában kell igazolni. Ezenkívül néhány tartomány (Bréma, Alsó-Szászország, Észak-Rajna-Vesztfália stb.) a jogi nyelv alapos ismeretét is elöírja. Nem elöírás, hogy a kérelmező az adott tartományban lakóhellyel rendelkezzen, így ha egy másik tartományba költözik, a felesketése akkor sem veszíti hatályát (vö. Stanek 2011: 44).

További általános szabályként elmondható, hogy egyszerre nem lehet több tartományban is kérelmezni a felesketést vagy a nyilvános kirendelést (pl. HmbDolmG $§ 1$ (1) 4. pont vagy DolmG LSA § 3 (1) 5. pont). Az alsó-szászországi törvények viszont ezt nem tiltják meg kifejezetten:

Azon kérelmezők esetében, akiket egy másik tartomány törvénye alapján általánosan felesketett tolmácsként, illetve felhatalmazott vagy nyilvánosan kirendelt fordítóként vettek nyilvántartásba, a szakmai alkalmasságot az általános felesketésre, illetve felhatalmazásra vagy nyilvános kirendelésre vonatkozó igazolás bemutatásával is elegendő igazolni. (NJG §23 (4))

A felesketési követelmények és a minőségi elöírások egységesítése érdekében a németországi Fordítók és Tolmácsok Szövetsége (BDÜ) kezdeményezésére 2019 novemberében a Német Szövetségi Parlament (Bundestag) egy szövetségi szinten érvényes bírósági tolmácsolási törvényt (GDolmG) fogadott $\mathrm{el}^{35}$, amely a tervek szerint 2021. július 1-jén lép hatályba. A törvénnyel szemben megfogalmazott egyik kritika az, hogy a fordítókkal kapcsolatban semmilyen szabályozást nem tartalmaz, a felesketés csak az EU-tagországok állampolgáraira vonatkozik, a törvény nem határozza meg pontosan a „bírósági tolmácsolás” fogalmát, továbbá hogy nem írja elő kötelezően a német jogi nyelv ismeretét (lásd az Igazságügyi Tolmácsok és Fordítók Országos Fórumának állásfoglalását ${ }^{36}$ ).

Végezetül érdemes megemlíteni, hogy a németországi bíróságok 2013. november 1-je óta a GVG $§ 185$ (1a) értelmében már videótolmácsolást („video remote interpreting") is alkalmazhatnak: 
A bíróság engedélyezheti, hogy a tolmács a tárgyalás vagy kihallgatás során egy másik helyen tartózkodjon. A tárgyalást vagy kihallgatást valós időben kép és hang formájában kell továbbítani a tárgyalóterembe és a tolmács tartózkodási helyére.

A videótolmácsolás bírósági alkalmazása ellen az Igazságügyi Tolmácsok és Fordítók Országos Fóruma ${ }^{37}$ foglalt állást, okokként többek között a manipuláció lehetőségét, a technikai hiányosságokat és a magas beruházási költségeket nevezték meg.

\section{Nyelvi közvetítők}

Az utóbbi években felgyorsuló globális migráció következtében Németországban is rohamosan megnőtt a kereslet a képzési kínálatban nem szereplö egzotikus nyelveken dolgozó fordítók/tolmácsok iránt (arab, dari/fárszi, kurmandzsi, tigrinya, szomáli, urdu stb., esetenként több tízmillió anyanyelvi beszélővel ${ }^{38}$ ). Mivel ezekből a nyelvekből kevés képzett szakember áll rendelkezésre, számos gyakori élethelyzetben (menedékjogi eljárások, oktatás és egészségügy stb.) úgynevezett „,nyelvi közvetítők" bevonására van szükség, akik többnyire a közösségi tolmácsolás (,community interpreting”) keretén belül közvetítenek a szakemberek és a nem anyanyelvüek között. A „nyelvi közvetítő” kifejezés (amely szintén egy szabadon használható elnevezés) azt a tényt hivatott tükrözni, hogy ilyen esetekben nem egy képzett vagy felesketett fordító és tolmács biztosítja a felek közötti kommunikációt. Egyébként maga a kifejezés eredetileg az NDK-ban és részben Nyugat-Németországban korábban is használatos volt a tolmácsok és fordítók gyüjtőneveként (több egyetemen még „diplomás nyelvi közvetítő” képzés is müködött), és még ma is ebben az értelemben használatos.

A nyelvi közvetítöknek gyakran nem a német az anyanyelvük, a nyelvi közvetítést többnyire önkéntes alapon a szabadidejükben végzik, és általában nem vállalnak el olyan megbízásokat, amelyeknél profi tolmácsokra vagy fordítókra van szükség. A fentiekből következik, hogy a laikus tolmácsolásnak megvannak a maga árnyoldalai, mint ahogy erre a Németországi Szabadúszó Fordítók és Tolmácsok Szövetségének (Deutscher Verband der freien Übersetzer und Dolmetscher) egyik írása is felhívja a figyelmet ${ }^{39}$. Ebben többek között azt kifogásolják, hogy a nyelvi közvetítőként dolgozó tolmácsokkal szemben túl alacsony követelményeket támasztanak (elegendő valamennyire ismerniük az adott nyelveket), és hogy bizonyos jelenségek miatt (túlzott önbecsülés, szerepkonfliktus, diszkrimináció, az anyaországi kormánnyal szembeni elkötelezettség) elég gyakran félrefordítják vagy félretolmácsolják az üzenetet. Mivel azonban a tevékenységüknek nincsen jogi következménye, hibás teljesítés esetén semmilyen jogi követelést nem lehet érvényesíteni velük szemben.

Bár a nyelvi és integrációs közvetítők ma már számos továbbképzési tanfolyam közül választhatnak, amelyek elsődlegesen az alapvető ismeretek és készsé- 
gek (semlegesség, megbízhatóság, szociális készségek stb.) átadására irányulnak, a nyelvi közvetítés jelenleg egyetlen egyetem szakkínálatában sem szerepel, viszont például a mainzi népföiskolán ${ }^{40}$, Saarbrückenben ${ }^{41}$ vagy Potsdamban ${ }^{42} a b-$ szolválni lehet egy szövetségi szinten egységes és a kereskedelmi és iparkamara által tanúsított kb. 150 tanórás tanfolyamot.

\section{6. Összefoglalás}

A fordító és tolmács szakma - részben a technológiai újítások miatt - állandó változáson megy keresztül, ami sok esetben a képzési rendszerben is tükröződik, gondoljunk csak az átdolgozott IHK-vizsgákra vagy az új alap- és mesterképzési szakok bevezetésére. A bolognai reform óta a németországi egyetemi fordító- és tolmácsképzés felépítése túlnyomórészt egységes képet mutat, ám a tartományi szinten szabályozott (állami) vizsgák, valamint a szintén tartományi hatáskörbe eső felesketési és felhatalmazási gyakorlat szabályozása terén továbbra is komoly különbségek vannak, ami megnehezíti a németországi képzési rendszer egységes kezelését. A különféle elnevezések és az eltérő követelmények (vizsgák, nyelvi ismeretek, jogi nyelv ismerete) könnyen összezavarják a laikusokat, és teljes joggal kiváltják a szakemberek ellenérzését. A szakmai szervezetek már régóta próbálnak megoldást keresni erre a helyzetre, és egyre inkább érzékelhető valamiféle egységesítési tendencia (például az új bírósági tolmácsolási törvény formájában), ám jelentős áttörést még nem minden területen sikerült elérni. Ehhez jön még a kisebb nyelveken dolgozó tolmácsok és fordítók iránt megnövekedett igény, amely a közeljövőben valószínüleg tovább nő. Egyelöre még nyitott kérdés, hogy a nyelvi közvetítők hogyan illeszthetök be a képzési rendszerbe, és hogyan hangolhatók össze a meglévő struktúrákkal, a szakmai követelményekkel, illetve a szakmaetikai értékekkel. Ezekre és az ehhez hasonló kérdésekre, például, hogy a közvetített képzési tartalmak megfelelnek-e a piacspecifikus követelményeknek, egy külön cikkben érdemes kitérni.

\section{Jegyzetek}

${ }^{1}$ Szeretnék köszönetet mondani Prof. Heike Jüngstnek (Würzburg-Schweinfurti Alkalmazott Tudományi Föiskola), valamint Cornelia Groethuysennek, a BDÜ alelnökének a munkám során nyújtott szakmai segítségért és az értékes észrevételekért.

${ }^{2}$ https://www.uni-heidelberg.de/fakultaeten/neuphil/iask/sued/seminar/seminar.html (Utolsó megtekintés: 2019. június 29.)

${ }^{3}$ https://theologie.uni-heidelberg.de/studium/interesse/faecher/uebersetzwiss ma.html (Utolsó megtekintés: 2019. június 29.)

${ }^{4}$ https://www.buecher-magazin.de/magazin/besondere-buecher/botschaften-aus-babel/ feuerprobe-fuer-das-uebersetzen (Utolsó megtekintés: 2019. június 29.) 
5 A korábbi szinkron módon tolmácsolt konferenciákkal kapcsolatban lásd https://web.archive.org/web/20200704000201/https:/aiic.net/page/6625/early-history-of-simultaneousinterpretation-equipment/lang/1 (Utolsó megtekintés: 2020. augusztus 3.)

6 https://by.bdue.de/ueber-uns/verbandsgeschichte/ (Utolsó megtekintés: 2020. február 7.)

7 https://fb06.uni-mainz.de/70-jahre-ftsk/ (Utolsó megtekintés: 2019. június 29.)

$8 \mathrm{https://www.ifa.fau.de/institut/geschichte/} \mathrm{(Utolsó} \mathrm{megtekintés:} \mathrm{2019.} \mathrm{június} \mathrm{29.)}$

9 https://uepo.de/2015/01/29/saarbruecken-uebersetzerstudiengaenge-durch-drastischesparvorgaben-der-landesregierung-gefaehrdet/ (Utolsó megtekintés: 2019. június 29.)

${ }^{10}$ https://www.sdi-muenchen.de/home/profil/kurzchronik/ (Utolsó megtekintés: 2019. június 29.)

${ }^{11}$ vö. https://uepo.de/2011/09/27/1967-dr-paul-schmidt-nimmt-abschied-vom-sdimunchen-es-hat-sich-gelohnt/ (Utolsó megtekintés: 2019. június 29.)

12 https://ialt.philol.uni-leipzig.de/institut/geschichte/ (Utolsó megtekintés: 2019. június 29.)

${ }^{13}$ Lásd a 3. sz. táblázatot is a 3.1.3. fejezetben

${ }^{14}$ https://www.km.bayern.de/ministerium/schule-und-ausbildung/staatliche-pruefungzum-uebersetzer-und-dolmetscher.html (Utolsó megtekintés: 2019. június 29.)

${ }^{15}$ Lásd https://www.hochschulkompass.de/promotion.html, azonban a Fordítástudomány nem szerepel az egyetem strukturált doktori programjában a https://www.philfak.unibonn.de/de/promotion/ausschreibung-zweite-kohorte-ws2018-19-verlangerung.pdf oldal (Utolsó megtekintés: 2020. január 28.)

${ }^{16}$ Lásd https://ialt.philol.uni-leipzig.de/studium/promotionsstudiengang/ (Utolsó megtekintés: 2020. január 28.)

17 https://www.uni-saarland.de/fileadmin/upload/forschen/gradus/PromR/35 Promotionsfaecherliste_Stand_20191007.pdf (Utolsó megtekintés: 2020. január 28.)

18 https://www.akad.de/weiterbildung/staatlich-gepruefter-uebersetzer/ (Utolsó megtekintés: 2020. január 28.)

${ }^{19}$ https://uepo.de/2018/08/08/dolmetscherschule-koeln-bietet-einjaehrige-online-vorbereitung-auf-staatliche-uebersetzerpruefung-in-sechs-fremdsprachen/ (Utolsó megtekintés: 2020. január 28.)

${ }^{20} \mathrm{Pl}$. a stuttgarti IDI-n (https://www.sprachschule-idi.de/ausbildung/uebersetzer), Heidelbergben (http://www.fuu-heidelberg-languages.com/uebersetzer_in/) vagy Dortmundban (http://www.allekurse.de/showcourse.aspx?courseId=4668)

${ }^{21} \mathrm{https}: / / w w w . p r o z . c o m / f o r u m / g e r m a n / 161555-$ staatlich gepr\%C3\%BCfter_\%C3\%9Cbersetzer_erfahrungen_und_hilfestellungen.html (Utolsó megtekintés: 2020. február 9.)

${ }^{22}$ https://bdue.de/fuer-dolmetscher-uebersetzer/wege-zum-beruf/staatliche-pruefung/ (Utolsó megtekintés: 2020. január 28.)

23 https://www.kmk.org/fileadmin/veroeffentlichungen beschluesse/2004/2004 03 12Richtlinie-Dolmetscher.pdf (Utolsó megtekintés: 2020. január 29.)

${ }^{24}$ Lásd a tolmácstörvényt is (DolmG BY) a 9. sz. táblázatban.

25 https://rp.baden-wuerttemberg.de/Themen/International/bersetzer_Dolmetscher/ psued_662920008i_Antrag.pdf (Utolsó megtekintés: 2020. január 29.)

26 2020-ban arab, kínai és holland nyelvből lehet vizsgát tenni, lásd https://www. $\mathrm{km}$.bayern.de/ministerium/schule-und-ausbildung/staatliche-pruefung-zum-uebersetzer-und-dolmetscher.html (Utolsó megtekintés: 2020. január 29.) 
${ }^{27}$ https://www.gesetze-bayern.de/Content/Document/BayUeDPO/true (Utolsó megtekintés: 2020. január 29.)

28 https://www.verkuendung-bayern.de/files/baymbl/2019/300/baymbl-2019-300.pdf (Utolsó megtekintés: 2020. január 29.)

${ }^{29}$ https://lehrkraefteakademie.hessen.de/sites/lehrkraefteakademie.hessen.de/files/Information $\% 20 z u m \% 20 \% \mathrm{C} 3 \% 9 \mathrm{CV} \% 202018$.pdf (Utolsó megtekintés: 2020. augusztus 3.)

${ }^{30}$ https://www.duesseldorf.ihk.de/produktmarken/weiterbildung/weiterbildungspruefungen/weiterbildungsabschluesse/uebersetzer-neue-verordnung--4072586 (Utolsó megtekintés: 2020. augusztus 3.)

${ }^{31}$ https://www.gesetze-im-internet.de/ bprv/BJNR115900017.html (Utolsó megtekintés: 2020. február 9.)

${ }^{32}$ A BDÜ adatai szerint (lásd https://bdue.de/der-beruf/wege-zum-beruf/ihk-pruefung/) Karlsruhéban, Regensburgban, Dortmundban és Koblenzben is található IHK vizsgaközpont, azonban az ezekkel az IHK-kirendeltségekkel való levelezés nyomán kiderült, hogy ezekben a városokban már nem lehet vizsgát tenni.

33 http://www.justiz-dolmetscher.de/Recherche/ (Utolsó megtekintés: 2020. február 7.)

${ }^{34}$ Lásd a bíróságok szervezetéről szóló törvény $§ 189$ (2) pontját is (https://www.gesetzeim-internet.de/gvg/_189.html), amely tolmácsokra és fordítókra is érvényes: „Ha egy tolmács [...] valamelyik tartományban a fordításra vonatkozóan [...] általános esküt tett, akkor az összes állami és tartományi bíróság előtt elegendő erre az esküre hivatkoznia."

35 https://www.buzer.de/Gerichtsdolmetschergesetz.htm (Utolsó megtekintés: 2020. február 9.$)$

${ }^{36}$ https://cdn.website-editor.net/a2a4e0e88c584e4188499336bcf27eb5/files/uploaded/BFJ \%2520Stellungnahme\%2520zum\%2520GDolmG-E\%25202019-1008.pdf(Utolsó megtekintés: 2020. február 9.)

${ }^{37}$ https://cdn.website-editor.net/a2a4e0e88c584e4188499336bcf27eb5/files/uploaded/BFJPositionspapier\%2520Videodolmetschen\%2520vor\%2520Gericht\%25202018-09-09.pdf (Utolsó megtekintés: 2020. február 9.)

38 http://www.uebersetzerportal.de/bilder2/bamf-kurzanalyse asyl 2016.pdf, 6. oldal (Utolsó megtekintés: 2020. február 9.)

39 https://dvud.de/2016/05/dolmetscher-zwischen-allen-stuehlen/ (Utolsó megtekintés: 2020. február 8.)

${ }^{40}$ https://www.vhs-mainz.de/programmbereiche/arbeit-und-beruf/kw/bereich/kursdetails/kurs/XC35500/kursname/Sprachmittler-in+IHK-Zertifikat/kategorie-id/3/ (Utolsó megtekintés: 2020. január 28.)

${ }^{41}$ http://www.inbez.de/fileadmin/downloads/Sima_Sprachmittler.pdf (Utolsó megtekintés: 2020. január 28.)

42 https://www.ihk-potsdam.de/System/vst/2365988?region\&nuranmeldebare=true\&term in $I d=233340 \&$ sortAsc $=$ false \&nurKostenfreie $=$ false \&branchen \&geschaeftsfeld \& them en \& totalResults $=82 \&$ sortCol=Termin $\& \mathrm{id}=113852 \&$ zielgruppe \&ort $\&$ numPages $=2 \& \mathrm{vs}$ tTyp\&plzdistanz\&identnummer\&volltext\&bisdatum $=30.04 .2016 \&$ plzort\&foerdermoe glichkeiten $\&$ resultsPerPage $=50 \&$ actionId=NONE \& currentPage $=1 \&$ vondatum $=01.04$. 2016\#titleInText3 (Utolsó megtekintés: 2020. január 28.) 


\section{Irodalom}

AIIC 2013. On Comintern and Hush-a-Phone: Early History of Simultaneous Interpretation Equipment. Online: https://web.archive.org/web/20200704000201/https:/aiic.net/ page/6625/early-history-of-simultaneous-interpretation-equipment/lang/1 (Utolsó megtekintés: 2020. augusztus 3.).

Cebulla, M. (Hrsg.) 2012. Berufsrecht der Übersetzer und Dolmetscher. Berlin: BDÜ.

Horváth Sz. 2017. A bírósági tolmácsok/fordítók Németországban. In: Gellén, K. (szerk.) Ünnepi tanulmányok Bobvos Pál 65. születésnapjára. Szeged: Iurisperitus. 175-185.

Kalverkämper, H., Schippel, L. 2008. Simultandolmetschen in Erstbewährung: der Nürnberger Prozess 1945. Berlin: Frank \& Timme.

Nord, B. 2013. Das A und das O der Translationswissenschaft. Eine Studie zu den Inhalten der Einführungsvorlesung im Bachelor-Studiengang. In: Anne-Kathrin E., Susann H., Annette W. (Hrsg.) Alles hängt mit allem zusammen. Translatologische Interdependenzen. Festschrift für Peter A. Schmitt. Berlin: Frank \& Timme. 177-190.

Reinecke, J. 2017a. Geprüfter Übersetzer/Geprüfte Übersetzerin. Meckenheim: DIHK Verlag.

Reinecke, J. 2017b. Geprüfter Übersetzer | Musterprüfungsaufgaben. Meckenheim: DIHK Verlag.

Rüger, Ch. 2010. Neue Gesetze für beeidigte Dolmetscher in den Bundesländern: Umsetzung uneinheitlich. MDÜ 4/2010. 74-80.

Salevsky, H. 2009. Aspekte der Translation. Frankfurt: Peter Lang.

Schlesiger, A. 2017. Berufsschutz für Übersetzer und Dolmetscher in Deutschland: Vergangenheit - Gegenwart - und Zukunft? Berlin: Frank \& Timme.

SDI 2007. Prüfungsordnung der Externenprüfung im Bachelorstudiengang Übersetzen an der Hochschule für Angewandte Sprachen. Online: https://www.sdi-muenchen. de/fileadmin/Dokumente/Hochschule/Pruefungen/PO_Externenpruefung.pdf(Utolsó megtekintés: 2020. augusztus 3.).

Skalweit, L. 2017. Dolmetscher und ihre Ausbildung im Zeitalter der europäischen Expansion: Osmanisches Reich und Afrika. Berlin: Frank \& Timme.

Stanek, M. 2011. Dolmetschen bei der Polizei: Zur Problematik des Einsatzes unqualifizierter Dolmetscher. Berlin: Frank \& Timme.

Vermes A. 2017. Translator Training Programmes in Hungary and the United States of America. Romanian Journal of English Studies Vol. 14. No. 1. 81-88. DOI: https:// doi.org/10.1515/rjes-2017-0010 